\title{
A Novel, Conditionally Replicative Adenovirus for the Treatment of Breast Cancer That Allows Controlled Replication of E1a-Deleted Adenoviral Vectors
}

\author{
RUBEN HERNANDEZ-ALCOCEBA, MICHAEL PIHALJA, MAX S. WICHA, and MICHAEL F. CLARKE
}

\begin{abstract}
The efficiency of gene therapy strategies against cancer is limited by the poor distribution of the vectors in the malignant tissues. To solve this problem, a new generation of tumor-specific, conditionally replicative adenoviruses is being developed. To direct the replication of the virus to breast cancer, we have considered one characteristic present in a great proportion of these cancers, which is the expression of estrogen receptors (ERs). On the basis of the wild-type adenovirus type 5, we have constructed a conditionally replicative adenovirus (Ad5ERE2) in which the E1a and E4 promoters have been replaced by a portion of the pS2 promoter containing two estrogen-responsive elements (EREs). This promoter induces transcriptional activation of the E1a and E4 units in response to estrogens in cells that express the ERs. Ad5ERE2 is able to kill ER ${ }^{+}$human breast cancer cell lines as efficiently as the wild-type virus, but has decreased capacity to affect $\mathbf{E R}^{-}$cells. By complementation of the E1a protein in trans, Ad5ERE2 allows restricted replication of a conventional E1adeleted adenoviral vector. When a virus expressing the proapoptotic gene Bc1-xs (Clarke et al., Proc. Natl. Acad. Sci. U.S.A. 1995;92:11024-11028) is used in combination with Ad5ERE2, the ability of both viruses to induce cell death is dramatically increased, and the effect can be modulated by addition of the antiestrogen tamoxifen.
\end{abstract}

\section{OVERVIEW SUMMARY}

To obtain controlled replication of adenoviral vectors, the E1a transcription unit of the virus is usually placed under the control of a tumor-specific promoter. In the absence of a well-characterized tumor-specific promoter for breast cancer, we have used a portion of the pS2 promoter containing two estrogen response elements to control the expression of the E1a and $\mathrm{E} 4$ viral proteins. The result is a new virus (Ad5ERE2) that replicates preferentially in human breast cancer cell lines expressing estrogen receptors. Ad5ERE2 can be used to induce replication of an E1adeleted adenoviral vector by complementation of the E1a protein in trans. This cooperation can be inhibited by antiestrogenic drugs such as tamoxifen.

\section{INTRODUCTION}

\section{A} DENOVIRUSES HAVE GREAT POTENTIAL as vectors for cancer gene therapy, especially in those strategies that rely on the transduction of malignant cells with lethal genes. In this sce- nario, some of the weaknesses of these vectors for use in treating inherited diseases are irrelevant. For example, the lack of a sustained expression of the therapeutic gene is not an issue because the goal is to kill the cells. Moreover, a local stimulation of the immune system may help to eradicate the malignancy. The main impediment in using adenovirus vectors for the treatment of solid tumors is the poor distribution of the vector throughout the tumor. The killing of malignant cells by targeted delivery of lethal genes has been conceptually demonstrated in many preclinical studies using different approaches (Roth and Cristiano, 1997; Dranoff, 1998). However, to achieve a clinically significant benefit from cytotoxic viruses, some sort of amplification of the initial effect is required (Han et al., 1998).

In general, adenoviruses that contain suicide genes are replication incompetent by deletion of viral genes that are necessary for the replication of the virus. Adenovirus has five transcription units that are expressed before the onset of viral replication, called early units (E1a, E1b, E2, E3, and E4) (Shenk, 1996). The E1 a region encodes the first two polypeptides that accumulate after viral infection. Apart from inducing the entry of the host cell into the $S$ phase of the cell cycle, they have the ability to activate other transcription units in the viral genome 
(Lillie and Green, 1989). Without the E1 a gene the virus is virtually unable to replicate, and this is usually deleted in adenovirus-derived vectors. The E4 region comprises at least seven open reading frames (ORFs) whose functions are still not completely elucidated. The consequence of the deletion of this region is an inefficient production of viral particles due to defects in viral replication, late gene expression, host cell shutoff, and particle assembly (Halbert et al., 1985; Falgout and Ketner, 1987; Lusky et al., 1998). Interestingly, it has been shown that the E4 ORF 4 can induce p53-independent apoptosis (Marcellus et al., 1998; Shtrichman and Kleinberger, 1998).

A new generation of conditionally replicative adenoviruses, also called tumor-specific replication-restricted adenoviruses (TRRAs), has been developed to kill malignant cells in a controlled fashion (Vile et al., 2000). The goal is to obtain viruses that can replicate only in the tumor. In this way, an initial dose of the therapeutic virus will infect a limited number of cells, but the natural cycle of the virus will continue in cancer cells, with the subsequent replication, death of the host cell, and liberation of thousands of new viruses. Ideally, the process goes on until no more cancer cells are available for the virus to replicate, and it limits the spread of the virus to the tumor margins. At least four different conditionally replicative adenoviruses have already been developed, demonstrating the feasibility and great potential of this new approach. To direct the replication of the virus to cancer cells, two different basic strategies have been used so far. The first one led to the construction of d11520, an adenovirus that has a deletion in the E1b region (Bischoff et al., 1996). The E1b 55-kDa protein binds and inactivates $\mathrm{p} 53$ in the host cell, and this is necessary for its entry in the S phase of the cell cycle. Therefore, this virus can replicate only in cells with an abolished p53 function. Although this mechanism of action is controversial(Hall et al., 1998; Rothmann et al., 1998; Hay et al., 1999), the therapeutic responses obtained with this virus, now called ONYX-015, are promising (Heise et al., 1997, 1999; Kirn et al., 1998). A mutant adenovirus with a partial deletion in the E1a region has been described (Fueyo et al., 2000). The deletion unables the binding to the $\mathrm{Rb}$ protein, and hence limits the replication of the virus to cells with a disrupted $\mathrm{Rb}$ pathway, which is a common characteristic of many cancer cells.

The second strategy for producing replication-restriced adenoviruses consists of placing the E1 region under the control of tissue or tumor-specific promoters. The prostate-specific promoter and enhancer have been used to direct the viral replication to prostate cancer cells (Yu et al., 1999), and the $\alpha$-fetoprotein gene promoter has been used to target hepatocellular carcinoma cells (Hallenbeck et al., 1999). This method opens exciting possibilities for the treatment of many different malignancies, once a promoter is identified that is preferentially activated in the tumor. The search of such promoters can be optimized by using new techniques such as differential display (Peng and Vile, 1999) and serial analysis of gene expression (SAGE) (Velculescu et al., 1995), but the list of tumor-specific promoters is limited. An alternative approach is the use of tissue-specific promoters to restrict the replication of the virus to the affected organ. For example, in up to $70 \%$ of breast cancers, the malignant cells retain the expression of estrogen receptors (ERs) (Valavaara, 1997). In the presence of estrogens, these nuclear receptors can bind to a specific sequence (estro- gen response element, ERE) present in the promoter of certain genes, and activate their transcription (Tsai and O'Malley, 1994).

In this study we describe the construction and characterization of a new conditionally replicative adenovirus for the treatment of breast cancer. We have replaced the E1a and E4 promoters of the wild-type adenovirus type 5 by a portion of the pS2 promoter, which contains two EREs. This promoter can be activated by estrogens in cells expressing ERs, and transcription can be inhibited by antiestrogens such as tamoxifen. We show evidence that this virus preferentially kills $\mathrm{ER}^{+}$cells and can be used in combination with an E1a-deleted adenoviral vector to amplify the delivery of a proapoptotic gene to breast cancer cells.

\section{MATERIALS AND METHODS}

\section{Cell lines}

MCF7 (ATTC HTB 22), T47D (ATTC HTB 133), and BT474 (ATTC HTB 20) are $\mathrm{ER}^{+}$human breast cancer cell lines. MDAMB231 (ATTC HTB 26) and SKBR3 (ATTC HTB 30) are $\mathrm{ER}^{-}$human breast cancer cell lines. Cells were maintained in RPMI medium (BioWhittaker, Walkersville, MN) supplemented with $10 \%$ fetal bovine serum (HyClone, Logan, UT). For MCF7, T47D, BT474, and MDAMB231, insulin $(10 \mu \mathrm{g} / \mathrm{ml}$; GIBCO-BRL, Grand Island, NY) was added. HeLa (ATTC CCL 2) is an $\mathrm{ER}^{-}$human cervical cancer cell line, and it was maintained in Dulbecco's modified Eagle's medium (DMEM; GIBCO-BRL) supplemented with $10 \%$ fetal bovine serum. SUM-309PE cells are $\mathrm{ER}^{+}$human breast cancer primary cells, and were maintained in Ham's F-12 (BioWhittaker) supplemented with insulin $(5 \mu \mathrm{g} / \mathrm{ml})$, hydrocortisone $(1 \mu \mathrm{g} / \mathrm{ml})$, epidermal growth factor (EGF, $10 \mathrm{ng} / \mathrm{ml})$, and cholera toxin (100 $\mathrm{ng} / \mathrm{ml}$ ). When the experiment required depletion of estrogens, improved minimal essential medium (IMEM) without phenol red was used (GIBCO-BRL), supplemented with $2.5 \%$ charcoaldextran stripped serum (HyClone). Estradiol (17 $\beta$-estradiol) and 4-OH-tamoxifen were purchased from Sigma (St. Louis, MO). The 27-18 cell line (Gao et al., 1996) was derived from HEK293 cells after stable transfection with a plasmid expressing adenovirus E4 ORF 6 under the control of a mouse mammary tumor virus (MMTV) promoter. These cells were maintained in DMEM plus $10 \%$ fetal bovine serum and G418 $(1 \mathrm{mg} / \mathrm{ml}$; GIBCO-BRL). The expression of the E4 ORF 6 in these cells was induced by adding $10 \mu M$ dexamethasone (Gensia, Irvine, CA) to the culture medium. All culture media were supplemented with penicillin $(100 \mathrm{U} / \mathrm{ml})$, streptomycin $(100 \mathrm{U} / \mathrm{ml})$, and amphotericin B (Fungizone, $0.25 \mu \mathrm{g} / \mathrm{ml}$; BioWhittaker).

\section{Construction and characterization reporter plasmids}

The estrogen-responsive promoter (EREp) was obtained from the plasmid pERE2pS2CAT (Montano et al., 1996), kindly provided by B.S. Katzenellenbogen (University of Illinois, Urbana, IL). This plasmid contains a portion of the $\mathrm{pS} 2$ promoter $(-90 /+10 \mathrm{bp})$, plus two EREs. The fragment containing the promoter was liberated by digestion with EcoRI and $B s r I$, and subcloned in the $S m a I$ site of the luciferase reporter plasmid pGL2-Basic (Promega, Madison, WI). To verify the 
response to estrogens, the new construct (pBERE) was transfected into T47D, MCF7, or MDAMB231 cells using the FuGENE 6 reagent, as described by the manufacturer (Roche, Indianapolis, IN). The cells (typically $7.5 \times 10^{4} /$ well in a 12 -well plate) were seeded in estrogen-free medium and transfected 24 hr later, using $0.3 \mu \mathrm{g}$ of pBERE and $0.1 \mu \mathrm{g}$ of the plasmid pRLTK (Promega) in order to quantify the efficiency of transfection. To confirm the specificity of transcriptional activation, a promoterless reporter (pGL2-Basic) and a reporter with a constitutive simian virus 40 (SV40) promoter (pGL2-Control) were transfected under the same conditions. Six hours later, the transfection medium was removed and new medium was added containing the indicated treatments. After 14-18 hr, cells were lysed and analyzed for luciferase activity with the dual luciferase reporter assay system (Promega), as indicated by the manufacturer. The specific luciferase activity measured in a luminometer is presented as (firefly/Renilla) $\times 1000$ luciferase units.

\section{Construction of Ad5ERE2}

Modification of the adenoviral genome. To modify the regions containing the E1a and E4 promoters, we subcloned portions of the adenovirus type 5 genome in plasmids that allowed their manipulation by standard cloning techniques. For the E4 region, the EcoRI-BamHI fragment of the pAdTrack plasmid (kindly provided by B. Vogelstein, Howard Huges Medical Institute, Baltimore, MD) containing nucleotides 34931 to 35935 of the viral genome (He et al., 1998), was subcloned into the pUC19 vector (New England BioLabs, Beverly, MA). The new plasmid was called pUC19Track. To eliminate the E4 promoter, a deletion comprising nucleotides 35575 to 35818 was performed. To do this, the viral region comprising nucleotides 35233 to 35575 was amplified by polymerase chain reaction (PCR) using primers that introduced an $N r u$ I site at position 35575. The primers were $5^{\prime}$-AAACTGGTCACCGTGATTAAAAAG- ${ }^{\prime}$ and 5'-CCGTAGGATTCACCATCAGGTGTCGCGACGAGTGGTGTTTTTTTAA- $3{ }^{\prime}$. The latter primer contains a 22-bp random sequence at the $5^{\prime}$ end. In a similar way, the region comprising nucleotides 35818 to 35935 was amplified with primers that introduced an EclXI site at position 35818, and produced a 22-bp sequence complementary to the previous one. These primers were 5'-CACCTGATGGTGAATCCTACGGCGGCGGCCGACTCCGCCCTAAAACC- $3^{\prime}$ and $5^{\prime}$-CGATCATTA ATTAACATCATCAATAATAAT ATACC- ${ }^{\prime}$. The products obtained with these sets of primers were combined to obtain a fragment in which the E4 promoter is substituted by the complementary random sequence flanked by $\mathrm{NruI}$ and $E c l$ XI sites.

This fragment was amplified by PCR using the most external primers of the previous reactions, and was introduced in the $B s t \mathrm{E}_{2}-P a c \mathrm{I}$ sites of pUC19Track. We then engineered a second plasmid (pShutAd) containing the kanamycin resistance gene from pShuttle (He et al., 1998), the deleted E4 promoter region, and the E1a promoter-containing adenoviral sequence from nucleotides 1 to 1574 subcloned from the pTG3602 plasmid (Chartier et al., 1996), kindly provided by M. Mehtali (Transgène, Strasbourg, France). On the basis of pShutAd, we could introduce the ERE2 promoter into the E4 region, (NruI-EclXI sites, blunt ended). The deletion of the E1a promoter (nucleotides 341 to 499) was obtained by combination of two PCR fragments, following the same strategy that led to the deletion of the $\mathrm{E} 4$ promoter. The fragment comprising nucleotides 341 to 499 was amplified with the primers 5'AGCGCGTAATATTGAATTCGGGCCGCGGGGACTTTGA-3' and 5' ${ }^{\prime}$-TCTACTCGCTGGCACTCAAGAGTCGCGACTTGAGGAACTCAC- ${ }^{\prime}$. These primers incorporate EcoRI and $N r u$ I sites flanking the E1 a promoter, and a complementary tail to the fragment produced in the second PCR. The latter amplified the region comprising nucleotides 499 to 1339 . The primers used were 5'-CTCTTGAGTGCCAGCGAGTAGA- ${ }^{\prime}$ and $5^{\prime}$-TGCATTCTCTAGACACAGGTGATGTC$3^{\prime}$. Once the two portions were fused and amplified, the product was subcloned in the $S s p \mathrm{I}-X b a \mathrm{I}$ sites of pShutAd, and the E1a promoter could be substituted by the EREp promoter (NruI-EcoRI sites, blunt ended). Once the modifications of the E1 and E4 regions were completed, we used homologous recombination in Escherichia coli to introduce these changes in the whole adenovirus genome. The modified plasmid confers kanamycin resistance to the cells. It was cotransformed in BJ5183 cells with pTG3602, a plasmid that contains the wildtype adenovirus genome subcloned in a backbone with the ampicillin resistance genes. After electroporation, the cells were selected in LB plates containing kanamycin $(30 \mu \mathrm{g} / \mathrm{ml})$ and small colonies were screened by restriction endonuclease digestion. The DNA was purified from a single positive colony, and confirmed by automated sequencing of the modified regions.

Production and verification of the virus. Once the plasmid containing the modified adenovirus was obtained, it was digested with PacI to liberate the viral genome from the plasmid backbone. After phenol-chloroform extraction and ethanol precipitation, the DNA was transfected into $27-18$ cells by the LipofectAMINE method (Gibco-BRL), as described by the manufacturer. The cells were maintained in DMEM plus 5\% fetal bovine serum (FBS) and $10 \mu M$ dexamethasone to induce the expression of the E4 ORF 6 . When the cytophatic effect was evident in the monolayer (typically 6-8 days after transfection), the cells were collected and lysed by three rounds of freezing and thawing in phosphate-buffered saline (PBS) supplemented with $0.01 \% \mathrm{CaCl}_{2}$ and $0.01 \% \mathrm{MgCl}_{2}\left(\mathrm{PBS}^{++}\right)$. After spinning the lysate at $350 \times g$ to discard the cellular debris, the supernatant was used to infect a monolayer of 27-18 cells. Viral plaques were isolated from this monolayer, and the viral DNA was extracted to confirm the modifications by PCR. The supernatant containing viruses was digested for $2 \mathrm{hr}$ with autodigested pronase $(0.5 \mu \mathrm{g} / \mathrm{ml})$ in a buffer containing $10 \mathrm{~m} M$ Tris, $\mathrm{pH} 7.5$, and the DNA was phenol-chloroform purified and ethanol precipitated. Twenty nanograms was used in the PCRs. The region containing the E1 promoter was amplified with the primers 5'-TAGTGTGGCGGAAGTGTGATGTTG-3' (complementary to nucleotides 104 to 128 of the adenovirus sequence) and 5'-TCTTCGGTAATAACACCTCCGTGG-3' (complementary to nucleotides 577 to 600). The region containing the E4 promoter was amplified with the primers $5^{\prime}$ AAACTGGTCACCGTGATTAAAAAG-3' (complementary to nucleotides 35233 to 35251) and 5'-CCGTAGGATTCACCATCA GGTGTCGCGACGAGT GGTGTTTTTTTAA-3' (complementary to the end of the adenoviral genome). The PCR fragments were digested with $C l a \mathrm{I}$, a restriction endonuclease 


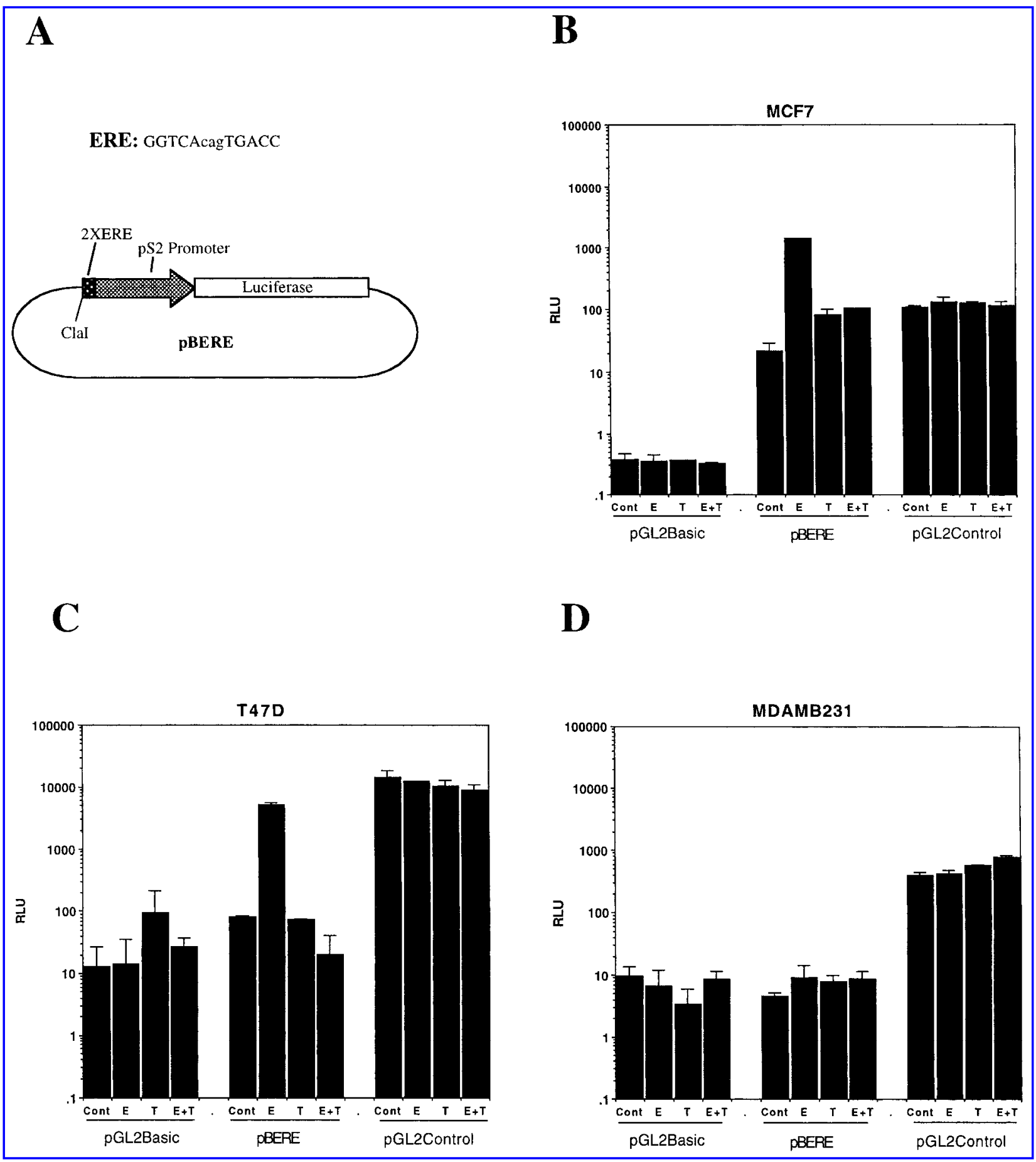

FIG. 1. Construction and characterization of the estrogen-inducible promoter (EREp). (A) Schematic representation of pBERE, a reporter plasmid expressing the luciferase gene under the control of the EREp promoter. The ERE consensus sequence is indicated. The gray arrow represents the $\mathrm{pS} 2$ promoter fragment (nucleotides -90/+10). Two EREs are subcloned upstream of this region (dark dotted box), and the position of the ClaI site is indicated. (B) ER ${ }^{+}$MCF7 human breast cancer cells were transfected with $0.3 \mu \mathrm{g}$ of either pGL2Basic, pBERE, or pGL2Control reporter plasmids, together with $0.1 \mu \mathrm{g}$ of the pRLTK Renilla luciferase plasmid to correct for efficiency of transfection. Phenol red-free medium and $2.5 \%$ charcoal-dextran stripped serum were used. After $6 \mathrm{hr}$, the medium was changed and cells were left untreated (Cont), or treated with $2.5 \mathrm{n} M 17 \beta$-estradiol (E), $2.5 \mu M 4-\mathrm{OH}$ tamoxifen $(\mathrm{T})$, or both $(\mathrm{E}+\mathrm{T})$, as indicated on the horizontal axis. Sixteen hours later, cells were lysed and both firefly and $R e$ nilla luciferase activities were measured in protein extracts. The columns represent in logarithmic scale the relative luciferase units $\left(\right.$ RLU) of (firefly/Renilla) $\times 1000$. (C and D) The results of the same kind of assay performed in the ER ${ }^{+}$T47D and ER $^{-}$ MDAMB231 human breast cancer cell lines, respectively. The assay was repeated three times with similar results. 
site that is present in the EREp promoter, but not in this region of the wild-type virus. Large-scale preparations of the virus were produced in 27-18 cells and purified by cesium chloride centrifugation. Titrations were made by plaque forming assay, and multiplicity of infection (MOI) refers to plaque-forming units (PFU) per number of cells.

\section{Analysis of transcriptional activation of Ela and E4 units}

To analyze the responsiveness of the EREp promoter in the context of the adenoviral genome, we performed Northern blot assays of cells infected with Ad5ERE2. MCF7 cells $\left(2 \times 10^{6}\right.$ cells/60-mm plate) were pretreated for $12 \mathrm{hr}$ in estrogen-free medium. Infection was performed for $1 \mathrm{hr}$ in $1 \mathrm{ml}$ of $\mathrm{PBS}^{++}$. The infection medium was then removed and the cells were incubated for $9 \mathrm{hr}$ in the treatment medium. Total RNA was extracted with the Trizol reagent (GIBCO-BRL), and $10 \mu \mathrm{g}$ of RNA was formaldehyde-formamide denatured, fractionated in a $1.2 \%$ agarose gel with $2.2 \mathrm{M}$ formamide, and transferred to a nylon membrane (Hybond-N+; Amersham, Buckinghamshire, UK). The E1a probe consisted of the 998-bp $S s p \mathrm{I}-\mathrm{Xba \textrm {I }}$ fragment from the adenoviral genome (nucleotides 341 to 1339 ), and the E4 probe was the 800 -bp SspI-AsnI fragment (nucleotides 34634 to 35419 ). They were radiolabeled by use of a random primed DNA labeling kit (Roche). The membrane was prehybridized for $2 \mathrm{hr}$ at $68^{\circ} \mathrm{C}$ in ExpressHyb hybridization solution (Clontech, Palo Alto, CA) in the presence of salmon sperm DNA $(1 \mathrm{mg} / \mathrm{ml})$ and tRNA $(1 \mathrm{mg} / \mathrm{ml})$. Hybridization was at $68^{\circ} \mathrm{C}$ for $1 \mathrm{hr}$ with probe at $2 \times 10^{6} \mathrm{cpm} / \mathrm{ml}$. The membrane was then washed with $2 \times \mathrm{SSC}, 0.1 \%$ sodium dodecyl sulfate (SDS) at room temperature for $20 \mathrm{~min}$, and twice with $0.1 \times \mathrm{SSC}, 0.1 \% \mathrm{SDS}$ at $50^{\circ} \mathrm{C}(1 \times \mathrm{SSC}$ is $0.15 \mathrm{M}$ $\mathrm{NaCl}$ and $15 \mathrm{~m} M$ sodium citrate, $\mathrm{pH}$ 7.0). Finally, it was autoradiographed. To confirm the homogeneous RNA loading and hybridization, we used the same membranes and hybridized them with a mouse $\beta$-actin probe.

\section{Cytopathic effect and viability of cells}

After infection of the cell lines with a wild-type adenovirus (Ad5WT) or Ad5ERE2, the appearance of cytopathic effect (rounding and detachment) was monitored and cells were photographed with a digital camera (Pixera, Los Gatos, CA). To quantify the viability of cells, the MTT assay was used (Sigma). At the time of analysis, $25 \mu \mathrm{l}$ of thiazolyl blue (MTT, $5 \mathrm{mg} / \mathrm{ml}$ ) solution was added to the cells cultured in $100 \mu \mathrm{l}$ of medium (96-well plate). Five hours later, $100 \mu \mathrm{l}$ of solubilization solution $(20 \%$ [w/v] SDS in $50 \%$ [v/v] $N, N$-dimethylformamide) was added, and $12 \mathrm{hr}$ later the absorbance at $600 \mathrm{~nm}$ was read in a spectrophotometer. When the experiment was performed in 12-well plates, cells were washed with $1 \mathrm{ml}$ of PBS before adding the MTT reagent $(250 \mu \mathrm{l}$ for $1 \mathrm{ml}$ of culture medium/well), and $1 \mathrm{ml}$ of solubilization solution was added 5 hr later. The significance of the differences observed was analyzed with the $t$ test.

\section{X-Gal staining of cells in culture}

To analyze the complementation of the E1a deficiency of adenoviral vectors with Ad5ERE2, an E1a-deleted vector expressing the $\beta$-galactosidase (lacZ) gene, Ad5LacZ, (Ealovenga et al., 1996), was coinfected with Ad5ERE2. The cells infected with Ad5LacZ can be identified in the monolayer by fixing and staining with the substrate 5-bromo-4-chloro-3-indolyl- $\beta$-Dgalactopyranoside (X-Gal), which produces a blue precipitate on hydrolysis by the enzyme $\beta$-galactosidase. The monolayers were fixed for $5 \mathrm{~min}$ in a solution containing $5.4 \%(\mathrm{w} / \mathrm{w})$ formaldehyde and $0.8 \%(\mathrm{w} / \mathrm{w})$ glutaraldehyde in PBS. The fixative was then removed and the cells were covered with staining solution and incubated at $37^{\circ} \mathrm{C}$ until the blue precipitate appeared. The staining solution contained X-Gal $(1 \mathrm{mg} / \mathrm{ml}$; GIBCO-BRL), $2 \mathrm{mM} \mathrm{MgCl} 2,5 \mathrm{~m} M \mathrm{~K}_{3} \mathrm{Fe}(\mathrm{CN})_{6}$, and $5 \mathrm{~m} M$ $\mathrm{K}_{4} \mathrm{Fe}(\mathrm{CN})_{6}$ in PBS. Finally, the number of blue cells per field was counted in duplicate wells.

\section{In vivo assays in nude mice}

The antitumor effect of Ad5ERE2 was tested in human tumor xenografts implanted in 5- to 7-week-old BALB/c $n u / n u$ mice (Harlan, Indianapolis, IN). Estradiol pellets $(0.72 \mathrm{mg}$ of $17 \beta$-estradiol, 60-day release; Innovative Research of America, Sarasota, FL) were implanted subcutaneouslyin the mice. Three days later, $5 \times 10^{6} \mathrm{MCF} 7$ cells were resuspended in serum-free RPMI plus 20\% Matrigel (Collaborative Biomedical Products, Bedford, MA) and injected subcutaneously in the back flanks. T47D cells were resuspended in PBS and injected in the mammary fat pad. When tumors reached a volume of approximately $100 \mathrm{~mm}^{3}$, viruses were diluted in $50 \mu \mathrm{l}$ of PBS and injected intratumorally with a Hamilton syringe.

\section{RESULTS}

Construction and characterization of reporter plasmids containing a promoter that responds to estrogen in $\mathrm{ER}^{+}$cells and can be inhibited by tamoxifen

To obtain a promoter that would be preferentially active in breast cancer cells, we used a construct (pBERE) containing a fragment of the human $\mathrm{pS} 2$ promoter $(-90 /+10 \mathrm{bp})$, with two EREs that confer its estrogen responsiveness (Berry et al., 1989). The pS2 protein is a member of the trefoil factors, which are normally expressed in the mucosa of the gastrointestinal tract (Ribieras et al., 1998). In addition, approximately $50 \%$ of human breast cancers show ectopic expression of $\mathrm{pS} 2 / \mathrm{TFF} 1$ (Rio and Chambon, 1990), generally in estrogen receptor-positive $\left(\mathrm{ER}^{+}\right)$cases. In fact, $\mathrm{pS} 2$ levels increase after estrogen treatment in the human breast cancer cell line MCF7 (Jeltsch et al., 1987). The combination of the $\mathrm{pS} 25^{\prime}$-flanking sequence and the EREs ensures a strong activation of the promoter in response to estrogens, only in $\mathrm{ER}^{+}$cells (Ekena et al., 1998). To characterize the promoter in our in vitro system, we subcloned it into a luciferase reporter plasmid (pGL2-Basic), and analyzed the activation by $17 \beta$-estradiol. Figure $1 \mathrm{~A}$ shows the structure of the plasmid containing the luciferase gene under the control of the estrogen responsive promoter (pBERE). Two different $\mathrm{ER}^{+}$human breast cancer cell lines (MCF7 and T47D) were transfected with the pBERE plasmid in a culture medium depleted of estrogens, and some wells were treated with $17 \beta$-estradiol as indicated in Fig. 1B and C. Both cell lines responded to estrogens with more than 50-fold induction. When the cells were treated with the antiestrogen 4-OH-tamoxifen, the estro- 
genic stimulation was abolished. To confirm the specificity of the activation, we transfected the cells with two additional luciferase reporter plasmids. pGL2-Basic is a promoterless plasmid and pGL2-Control has the luciferase gene under the control of a constitutive SV40 promoter. When these plasmids were used, there was neither significant increase of luciferase activity after treatment with estrogen, nor inhibition with 4-OH-tamoxifen. When the same experiment was performed with the $\mathrm{ER}^{-}$breast cancer cell line MDAMB231, no increase in luciferase activity was observed in cells transfected with the pBERE plasmid (Fig. 1D). These data indicate that the EREp promoter can be modulated by estrogenic agonists/antagonists only in cells that express ERs. An increase in luciferase activ- ity was observed in untreated $\mathrm{ER}^{+}$cells transfected with pBERE compared with the promoterless plasmid. The effect was more evident in MCF7 cells. This apparently unspecific activation can be due in part to the traces of estrogens present in the culture medium, because it was not observed in the $\mathrm{ER}^{-}$ cell line MDAMB231.

\section{Construction of Ad5ER2, an adenovirus with E1a and E4 regions controlled by the EREp promoter}

The data presented in Fig. 1 indicate that the EREp promoter is suitable for directing the expression of a gene to $\mathrm{ER}^{+}$cells. To obtain an adenovirus that will replicate preferentially in this

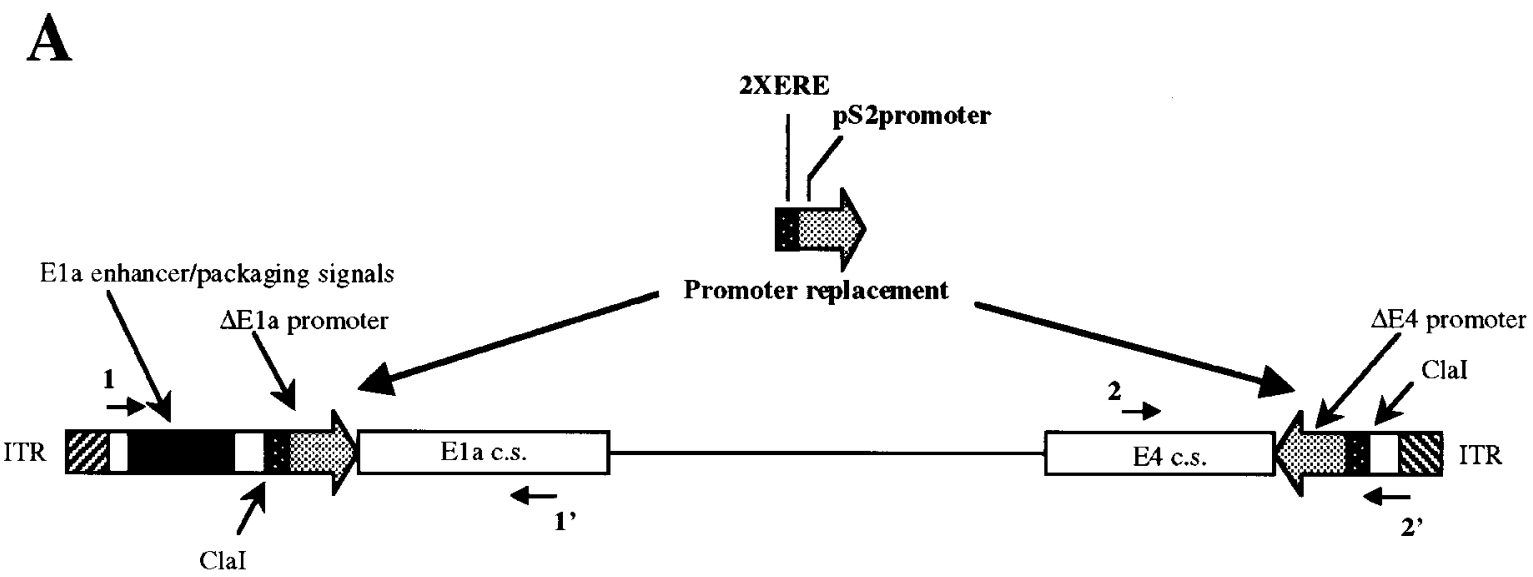

B

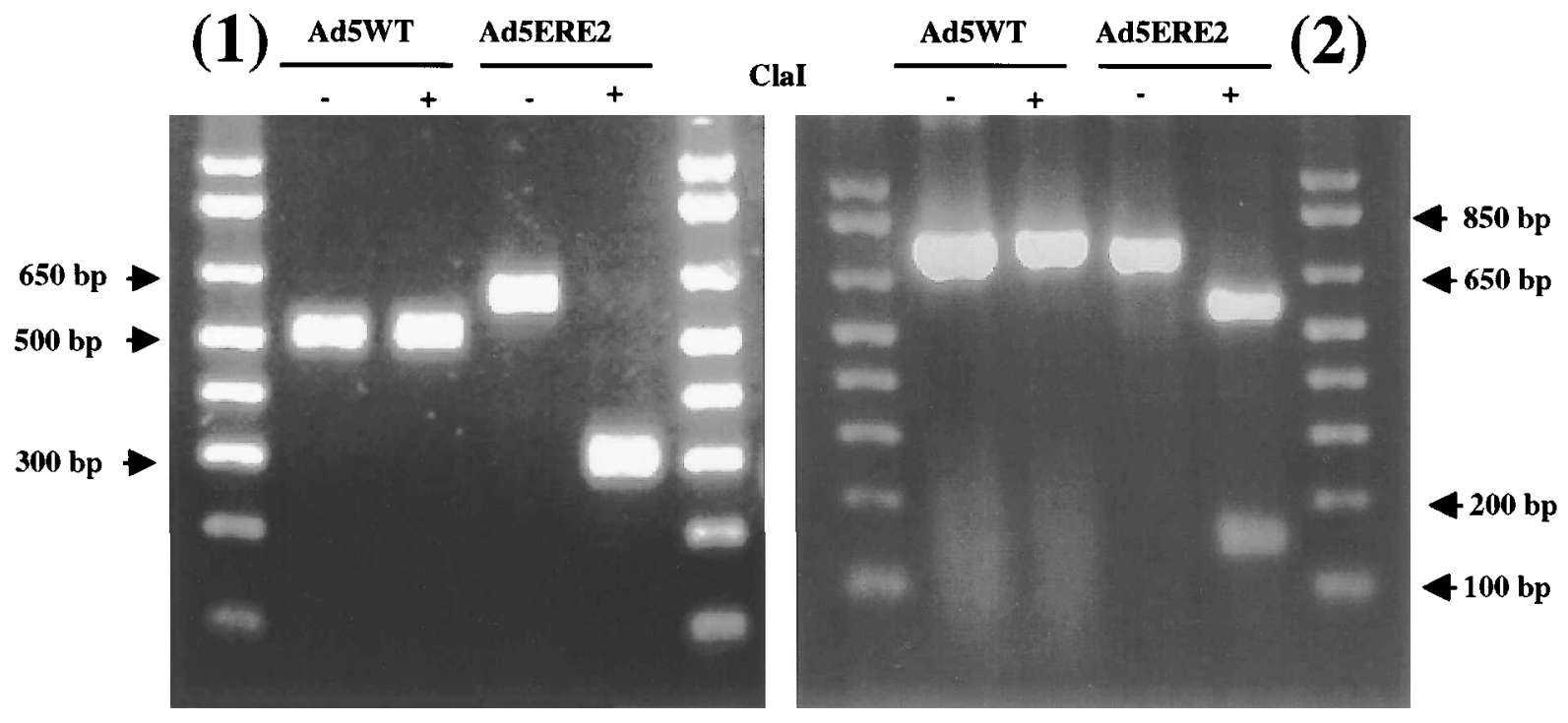

FIG. 2. Construction of Ad5ERE2. (A) Schematic representation of the modifications introduced in the adenovirus type 5 genome. The size of the viral regions is not proportional in the scheme. At the left end of the genome, the E1a enhancer/packaging signal is represented as a black box. The deleted E1a and E4 promoters are replaced by the EREp promoter. The positions of the PCR primers used to verify the structure of the virus are indicated as small arrows. (B) DNA was extracted from Ad5WT and Ad5ERE2, and PCRs were performed with primers 1 and 1' (panel 1), or primers 2 and 2' (panel 2). The + sign indicates digestion of the PCR fragment with the restriction endonuclease ClaI. The fragments were resolved in a $1.5 \%$ agarose gel. 
kind of cell, we placed the E1a and E4 regions of the virus under the control of this promoter. The wild-type promoters were deleted by a PCR strategy as described in Materials and Methods. The deletions comprise nucleotides 35575 to 35818 in the E4 promoter, and nucleotides 341 to 499 in the E1a promoter. Figure $2 \mathrm{~A}$ shows a schematic representation of the modifications introduced in the sequence of the adenovirus type 5 . This modified sequence was used to generate a new virus called Ad5ERE2, as described in Materials and Methods. The viral DNA was isolated and the modifications were confirmed by PCR (Fig. 2). In the E1a region, the wild-type adenoviral DNA yields a fragment of $500 \mathrm{bp}$, whereas the Ad5ERE2 fragment is $570 \mathrm{bp}$. In the case of the $\mathrm{E} 4$ region, the difference in size between both viruses is not as marked (700 bp for wild type and $680 \mathrm{bp}$ for Ad5ERE2). To verify further the presence of the EREp promoter and eliminate the possibility of contamination with wild-type virus, the fragments were isolated and digested with ClaI, a restriction enzyme whose recognition sequence is present in the EREp, but not in the wild-type promoter. As shown in Fig. 2, ClaI excised the PCR fragments of Ad5ERE2, but not the wild-type adenovirus.

The function of a promoter can be drastically affected by the presence of other regulatory elements, especially in the case of a complex viral genome (Shi et al., 1997; Vassaux et al., 1999). Therefore, we determined whether the EREp promoter is able to regulate the expression of the E1a and E4 units in the context of the adenoviral genome. To do this, we infected monolayers of MCF7 cells with Ad5ERE2 at an MOI of 5 virus/cell in the absence or presence of estrogens. Nine hours after infection, total RNA was extracted and the transcriptional activation of E1a and E4 regions was analyzed by Northern blot. There is a strong activation of the E1a and E4 mRNAs after estrogen treatment in this breast cancer cell line, which is drastically inhibited by the concomitant addition of the antiestrogen 4-OH-tamoxifen (Fig. 3). These data indicate that the E1a and E4 transcription units can be activated by an exogenous promoter after the deletion of the wild-type activator. In addition, the ERE2 promoter retained its ability to respond to estrogens.

\section{The cytopathic effect of Ad5ERE2 can be modulated by estrogens and tamoxifen, and correlates with the expression of the estrogen receptors in different cell lines}

Once we had verified the modulation of E1a and E4 viral gene expression in response to estrogenic agonists/antagonists, we investigated the capacity of the virus to induce cytopathic effect and death of the target cells. MCF7 cells were infected with Ad5ERE2 at an MOI of 1 PFU/cell for 8 days. Some cell monolayers were maintained in estrogen-free medium, whereas others were treated with $17 \beta$-estradiol, alone or in combination with tamoxifen, as indicated in Fig. 4. Eight days after infection, the viability of the cells was analyzed by the MTT assay (Carmichael et al., 1987). The result showed that the addition of $17 \beta$-estradiol to MCF7 cells infected with Ad5ERE2 drastically increases the capacity of the virus to kill the cells. The viability of the cells infected in the absence of estradiol decreased only $25 \%$ compared with the noninfected cells growing under the same conditions after 8 days. On the other hand, when estra- diol was added, virtually all the cells died, and tamoxifen partially inhibited this effect and allowed the survival of more than $50 \%$ of the cells.

To analyze if the modifications introduced in the virus affected its capacity to cause CPE and death of the cells in correlation with their ER status, we compared the effect of Ad5WT and Ad5ERE2 in six representative human cancer cell lines. Five of them (MCF7, T47D, MDAMB231, BT474, and SKBR3) are derived from breast cancer, whereas HeLa is an $\mathrm{ER}^{-}$cell line derived from a cervical cancer, which shows high permissivity for infection with the wild-type adenovirus. The cells were infected in the presence of $17 \beta$-estradiol in the culture medium. Figure 5A and B shows microphotographs of representative $\times 100$ magnification fields. In Fig. $5 \mathrm{~A}$, the $\mathrm{ER}^{+}$cell lines MCF7 and T47D, and the ER ${ }^{-}$cell lines MDAMB231 and HeLa, were infected at multiplicity of infection (MOI) of 5 virus/cell, and the monolayers were photographed 4 days after infection. In Fig. 5B, the $\mathrm{ER}^{+}$cell line BT474 and the $\mathrm{ER}^{-}$ cell line SKBR3 were infected at an MOI of 3 virus/cell, and were photographed 7 days after infection. All cell lines presented evident CPE when infected with Ad5WT, with disruption of the monolayer, rounding and detaching of cells. Ad5ERE2 caused similar changes in $\mathrm{ER}^{+}$cells. In contrast, $\mathrm{ER}^{-}$cells were more resistant to the effects of this virus, both at early (Fig. 5A) and late (Fig. 5B) times after infection. This demonstrates that the mutations introduced in the viral genome are compatible with efficient viral production, and that the regulation of the E1a and E4 transcription units has the desired effect on the cytotoxicity of the virus. To better quantify this effect, we again used the MTT assay to measure viability after

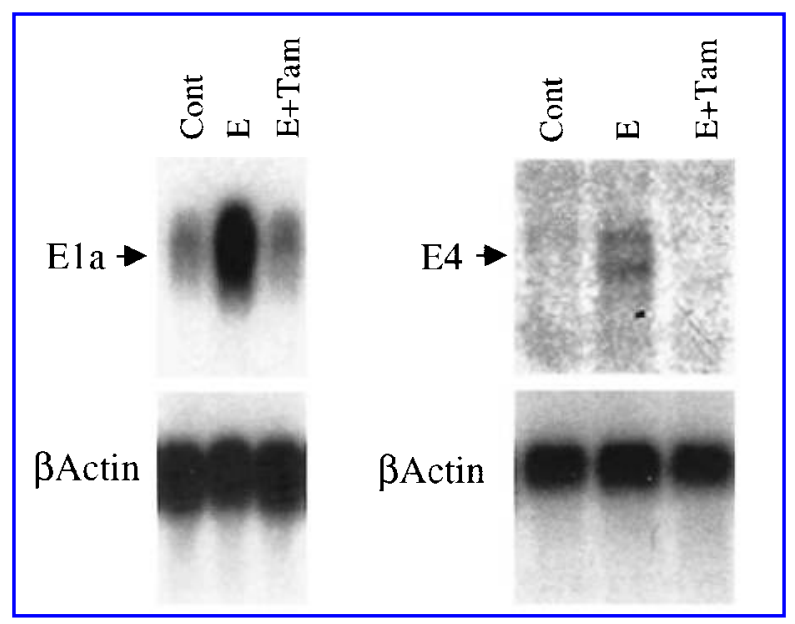

FIG. 3. Analysis of E1a and E4 transcription in Ad5ERE2infected MCF7 cells. MCF7 cells were maintained in phenol red-free medium with $2.5 \%$ charcoal-dextran stripped serum, and left untreated (Cont) or pretreated for $12 \mathrm{hr}$ with $2.5 \mathrm{nM}$ $17 \beta$-estradiol (E) or $2.5 \mathrm{n} M 17 \beta$-estradiol plus $2.5 \mu M 4-\mathrm{OH}$ tamoxifen $(\mathrm{E}+\mathrm{Tam})$ as indicated above each lane. Cells were then infected with Ad5ERE2 at an MOI of 5 virus/cell and total RNA was extracted after $9 \mathrm{hr}$ of infection. Northern blot analysis was performed with radioactive probes specific for the E1a, E4 regions or the constitutively expressed $\beta$-actin gene as a control. 


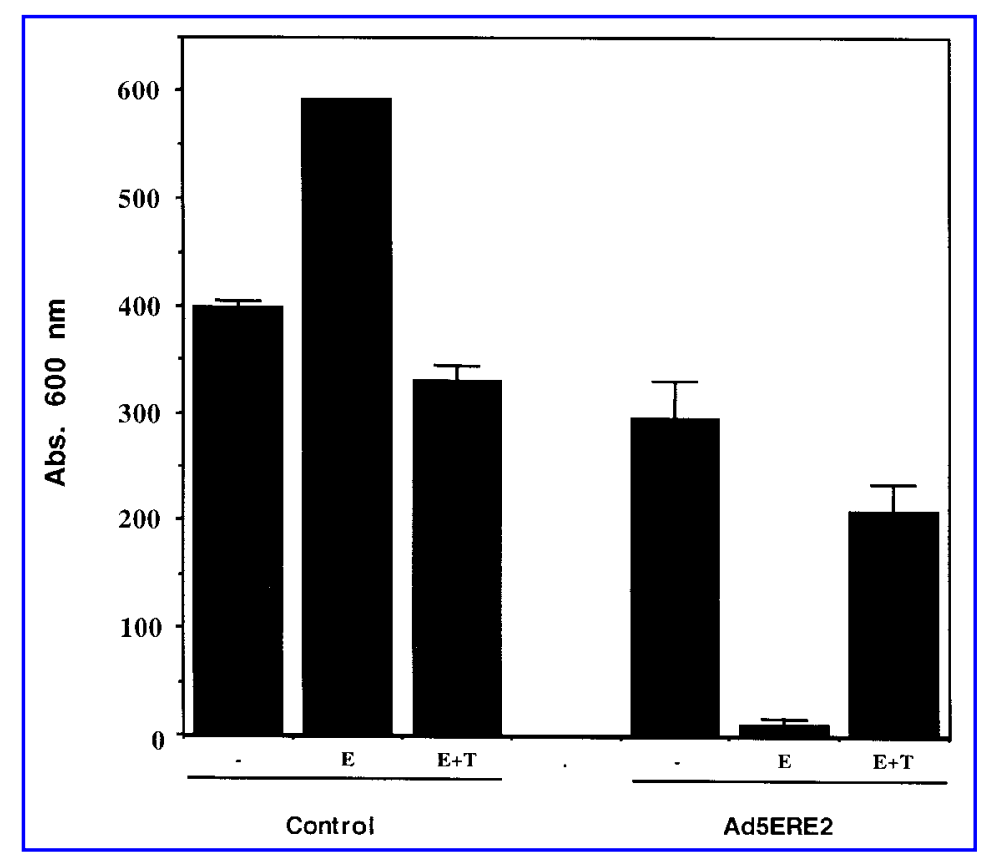

FIG. 4. Modulation of the cytotoxicity of Ad5ERE2 with estrogenic agonists/antagonists. MCF7 cells were maintained in phenol red-free medium with $2.5 \%$ charcoal-dextran stripped serum, and left untreated (-) or treated with $2 \mathrm{n} M 17 \beta$-estradiol (E) or $2 \mathrm{n} M 17 \beta$-estradiol plus $2.5 \mu M 4-\mathrm{OH}$-tamoxifen $(\mathrm{E}+\mathrm{T})$. One set of cells was infected with Ad5ERE2 at an MOI of 1 virus/cell, and another set was left uninfected (Control), as indicated on the horizontal axis. The monolayers were refed every 3 days, and 8 days after initiation of the infection the viability of the cells was analyzed by the MTT assay. The vertical axis indicates the absorbance at $600 \mathrm{~nm}$, which is proportional to the number of surviving cells.

infecting the cells with Ad5WT or Ad5ERE2 at an MOI of 3 virus/cell in the presence of $17 \beta$-estradiol. Cells were analyzed 3 days (Fig. 6A) or 7 days (Fig. 6B) after infection. In agreement with the CPE assay described above, Ad5ERE2 reduced the viability of MCF7, T47D, and BT474 cells as efficiently as Ad5WT $(p>0.05)$. On the other hand, MDAMB231, HeLa, and SKBR3 cells were at least two times more resistant to the cytotoxic effect of Ad5ERE2 compared with the wild-type virus. The result of this assay indicates that Ad5ERE2 is fully active in $\mathrm{ER}^{+}$cells, whereas there is a significant $(p<0.001)$ attenuation of the cytotoxic effect in the $\mathrm{ER}^{-}$cells.

Finally, we analyzed the effect of Ad5ERE2 on primary cells derived from a human breast cancer. The ER ${ }^{+}$SUM-309PE cells were infected at a low MOI (2 virus/cell), in order to test if this primary cell line can sustain the proliferation of the virus. The morphology and the viability of the monolayers were monitored 3, 5, and 8 days after infection. After 3 days, a small portion of cells started to show cytopathic effect, but the reduction of viability was modest (Fig. 7A and B). After 5 days, the cytopathic effect was widespread in the monolayer, and the viability was reduced $50 \%$ compared with the uninfected cells. Three days later, the reduction was more than $90 \%$, which suggest that Ad5ERE2 can efficiently infect, replicate in, and kill primary breast cancer cells.

\section{Use of Ad5ERE2 to allow replication of an E1-deleted adenovirus}

Apart from being a therapeutic tool itself, Ad5ERE2 can be used to complement the E1 a deficiency of already existing repli- cation-incompetent adenoviral vectors. There are several E1adeleted adenoviruses engineered to deliver lethal genes to cancer cells. Although they can efficiently deliver the gene and obtain high levels of expression that lead to the death of the infected cells, the cells that escape the initial infection are not affected and cause the relapse of the tumor.

The expression of E1 a proteins in Ad5ERE2 is controlled by a promoter that is preferentially activated in $\mathrm{ER}^{+}$cells. This means that if a cell is coinfected with Ad5ERE2 and an E1adeleted adenovirus, the same regulation of replication can apply to both viruses because Ad5ERE2 will provide the E1a protein in trans. To do this, we used an E1a-deleted adenovirus vector carrying the $\beta$-galactosidase gene under the control of a constitutive Rous sarcoma virus (RSV) promoter (Ad5LacZ), which allowed a quantification of the complementation. T47D cells were infected with a suboptimal amount of Ad5LacZ (MOI of 5), alone or in combination with Ad5ERE2 (MOI of 1). The infection was performed in estrogen-depleted medium and duplicate wells were left untreated or were treated with $17 \beta$-estradiol or $17 \beta$-estradiol plus tamoxifen. Five days later, the monolayers were fixed and incubated with the substrate $\mathrm{X}-\mathrm{Gal}$ to identify cells that were infected with Ad5LacZ. The average number of blue cells per field was counted and the results are graphically represented in Fig. 8. Surprisingly, when Ad5LacZ was used alone, the addition of estrogens reduced slightly but significantly the number of positive cells, and this effect was reversed by tamoxifen. Importantly, the addition of Ad5ERE2 stimulated more than four times the number of cells infected by Ad5LacZ under these conditions. The cooperation is mediated by the regulated expression of the E1a protein under the 
A
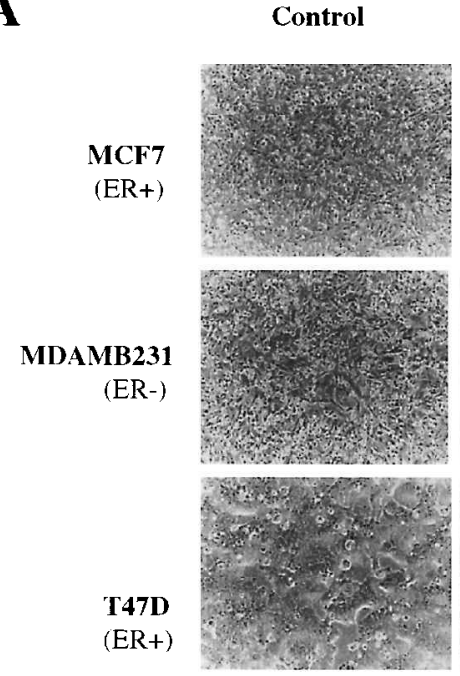

HeLa (ER-)
Ad5WT
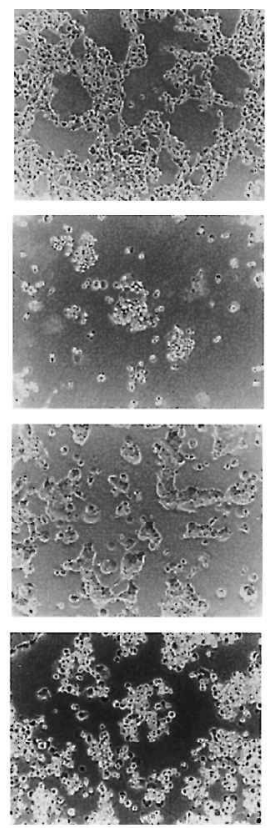

Ad5ERE2
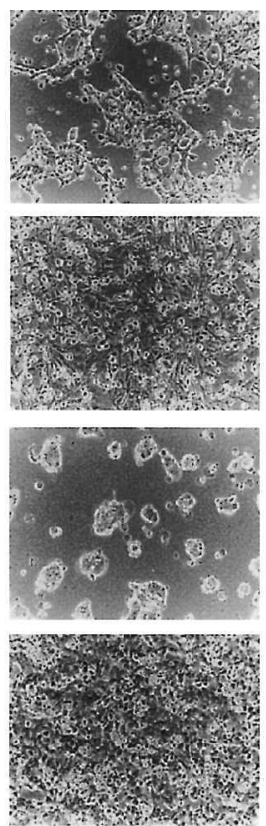

Ad5ERE2

B

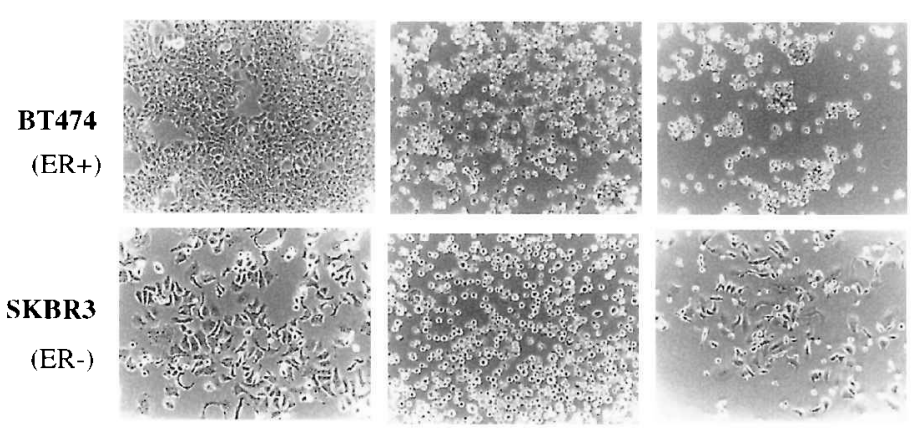

FIG. 5. Cytopathic effect of Ad5ERE2 on different cell lines. (A) The ER ${ }^{+}$cell lines MCF7 and T47D, and the ER ${ }^{-}$cell lines MDAMB231 and HeLa, were infected with Ad5WT or Ad5ERE2 at an MOI of 5 virus/cell in the presence of $1.5 \mathrm{n} M 17 \beta$-estradiol. The monolayers were photographed 4 days after infection. Representative fields (original magnification, $\times 100$ ) are shown. The control panels are noninfected cells maintained under identical conditions. The assay was repeated four times with similar results. (B) The same assay was performed with the $\mathrm{ER}^{+}$cell line BT474 and the $\mathrm{ER}^{-}$cell line SKBR3. Cells were infected for 7 days at an MOI of 3 virus/cell.

control of the EREp promoter, because tamoxifen inhibited the complementation. The preceding results suggest that a controlled replication of an E1-deleted adenovirus can be obtained by supplementation of the E1a protein with a conditionally replicative adenovirus. Next, we determined whether this strategy could be used to amplify the killing capacity of an E1adeleted adenovirus vector that expresses the proapoptotic gene Bcl-xs (Ad5Bcl-xs). It has been previously demonstrated that this virus can induce apoptosis in MCF7 cells in culture, and it inhibits the growth of tumors induced by injection of these cells in nude mice (Clarke et al., 1995; Ealovenga et al., 1996). How- ever, the inhibitory effect was modest and frequently administrations of the virus were required. The addition of a conditionally replicative adenovirus such as Ad5ERE2 could enhance the cytotoxic effect of Ad5Bcl-xs. To test this, we infected MCF7 cells with Ad5Bcl-xs at MOIs of 2 and 20 virus/cell, which is an amount of virus 5000-500 times lower than the dose needed to effectively kill these cells in culture. Additional monolayers were infected with Ad5Bcl-xs plus Ad5ERE2 at an MOI of 0.5 virus/cell in the presence of $17 \beta$-estradiol, with or without tamoxifen. Neither Ad5Bcl-xs nor Ad5ERE2 alone showed significant cytotoxicity when used at these low titers. 
A

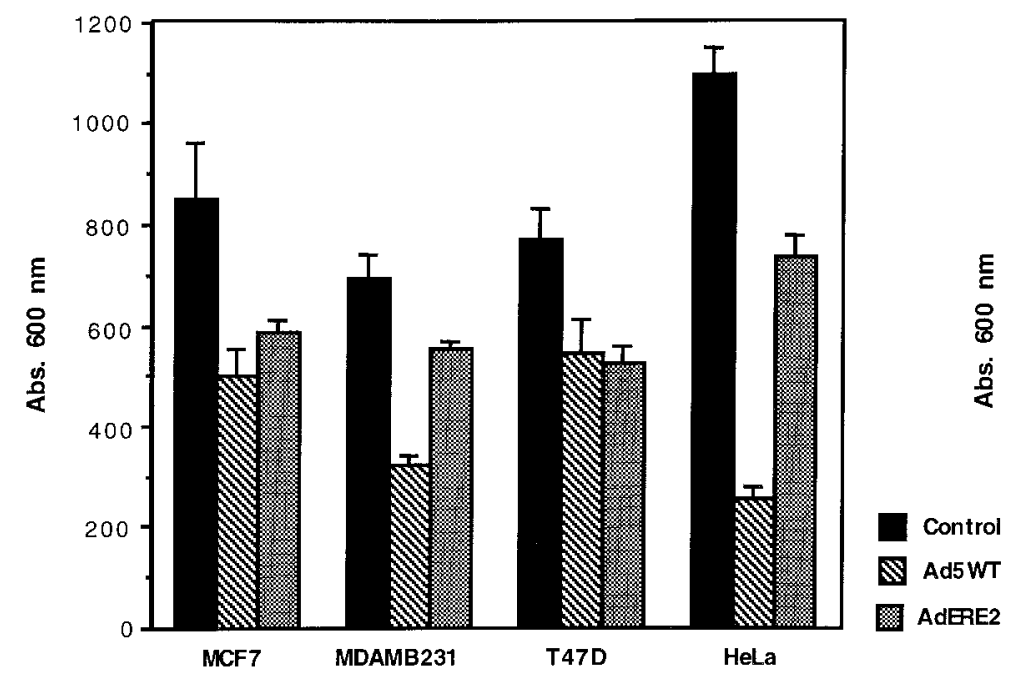

B

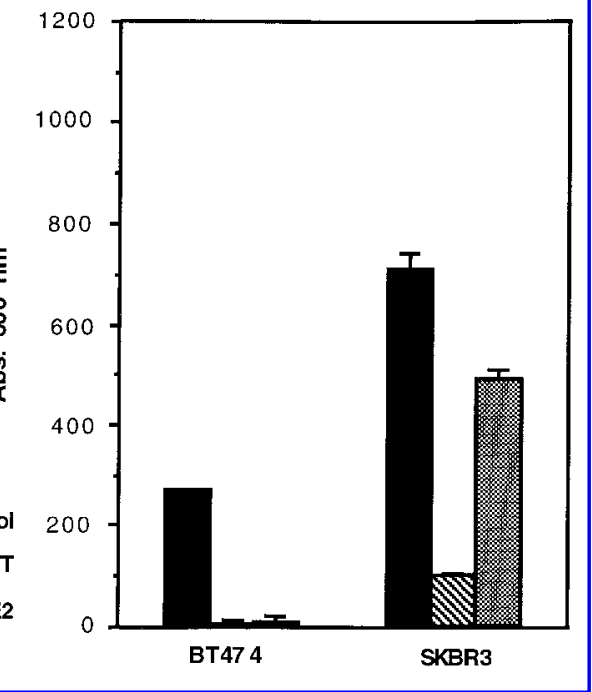

FIG. 6. Viability of various human cancer cell lines infected with Ad5ERE2. (A) The ER ${ }^{+}$cell lines MCF7 and T47D, and the $\mathrm{ER}^{-}$cell lines MDAMB231 and HeLa, were infected with Ad5WT (striped columns) or with Ad5ERE2 (gray columns) at an MOI of 3 virus/cell in the presence of $1.5 \mathrm{n} M 17 \beta$-estradiol. The viability of the cells was analyzed 3 days after infection by the MTT method. (B) The ER ${ }^{+}$cell line BT474 and the $\mathrm{ER}^{-}$cell line SKBR3 were infected as indicated above, and the viability was analyzed 7 days after infection.

The cells were refed every 3 days, and the viability was analyzed 8 days after infection. As shown in Fig. 9A, Ad5ERE2 greatly enhanced the killing effect of Ad5Bcl-xs. Again, the complementation elicited by Ad5ERE2 can be specifically inhibited with the antiestrogen tamoxifen. In Fig. 9B, the cells were treated basically as described above, but their viability was analyzed after 8 days of culture by the MTT assay. Ad5BclXs was used at a higher MOI (200 virus/cell), and the MOI of Ad5ERE2 was as low as 0.25 . The result indicates that this concentration of Ad5Bcl-xs was not lethal for MCF7 cells, whereas Ad5ERE2 caused a slight ( $p=0.07)$ decrease in viability. However, when both viruses were combined, $90 \%$ of the cells died at this time point. The addition of tamoxifen caused a significant $(p<0.005)$ protection from the lethal effect of this combination of viruses. In addition, a control E1a-deleted adenovirus without exogenous gene expression (Ad5 $\Delta \mathrm{E} 1 \mathrm{a})$ was coinfected with Ad5ERE2 under the same conditions. In contrast with Ad5Bcl-xs, no significant $(p=0.08)$ decrease in the viability of the cells was observed with this combination. This indicates that the amplification of the killing effect of Ad5Bclxs depends on the expression of the proapoptotic gene, and is not only the consequence of the replication of the vector. These results suggest that the effect of E1 a-deleted adenoviral vectors can be amplified in a controlled fashion by using a replicationconditional adenovirus that supplements the E1a protein.

\section{Antitumor effect in vivo}

The in vivo antitumor effect of Ad5Bcl-xs has already been demonstrated (Ealovenga et al., 1996), but the limitations of the first generation of adenoviral vectors to deliver genes in vivo markedly reduces their utility. We observed no significant inhibition of MCF7-induced tumor growth in nude mice when the virus was administered at $10^{8} \mathrm{PFU} /$ tumor once a week instead of twice a week (data not shown). Therefore, we tested the antitumor effect of the combination of Ad5Bcl-xs and Ad5ERE2 on human tumor xenografts under the same conditions. Tumors were induced by injection of MCF7 or T47D cells subcutaneouslyin estrogen-treatedmice. The viruses were administered intratumorally, once a week for 3 weeks. The data presented in Fig. 10 correspond to the percentage of reduction of tumor volume 20 days after the first viral administration. For MCF7 tumors, Ad5ERE2 was used at $10^{7} \mathrm{PFU} /$ tumor, alone or in combination with Ad5Bcl-xs, $10^{8} \mathrm{PFU} /$ tumor. For T47D tumors, the dose of Ad5ERE2 was $5 \times 10^{7} \mathrm{PFU} /$ tumor. In both tumors, Ad5ERE2 was able to reduce the average tumor volume more than $50 \%$, but only the combination of Ad5ERE2 and Ad5Bcl-xs obtained a drastic reduction of more than $90 \%$ (Fig. 10), much higher than the effect for five similar doses of Ad5Bcl-xs alone (data not shown).

\section{DISCUSSION}

The use of tumor-specific promoters to control the expression of viral genes is a promising method for the construction of therapeutic viruses. The lack of well-characterized promoters limits the systematic application of this technique. The systems to obtain drug-regulated gene expression constitute another new emerging field in gene therapy (Clarckson, 2000). 
A

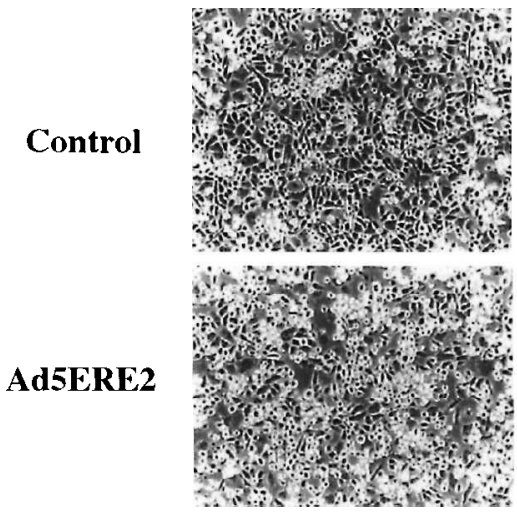

Day 3

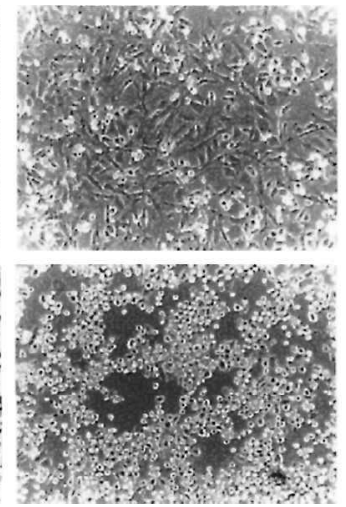

Day 5

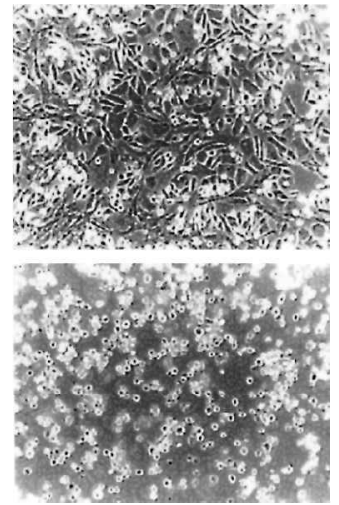

Day 8

B

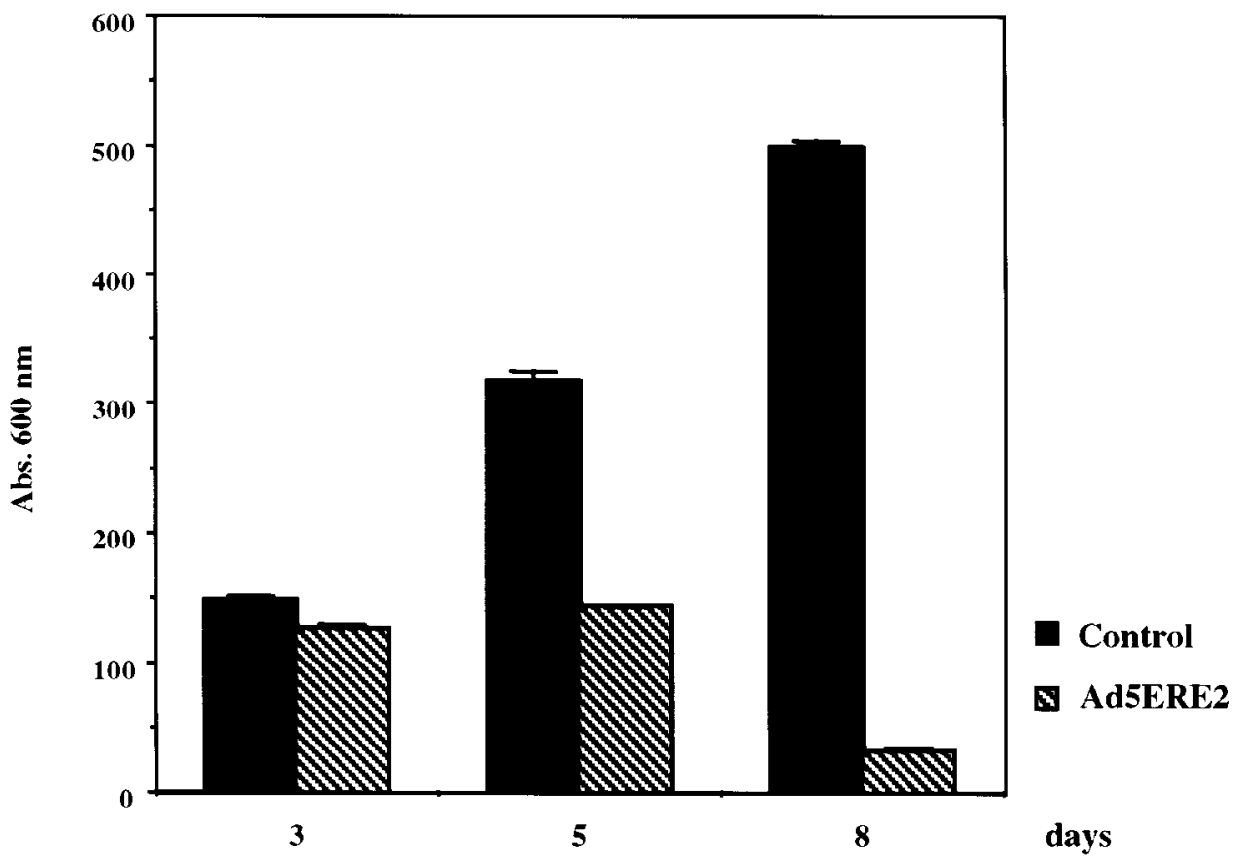

FIG. 7. Effect of Ad5ERE2 on primary human breast cancer cells. The ER ${ }^{+}$SUM-309PE cells were infected with Ad5ERE2 at an MOI of 2 virus/cell in the presence of $1.5 \mathrm{n} M 17 \beta$-estradiol, and were refed every 3 days. (A) Cells were photographed 3 , 5 , and 8 days after infection. Control refers to uninfected cells photographed at the same time. Representative fields (original magnification, $\times 100)$ are shown. (B) The viability of the cells was analyzed by the MTT method.

We are interested in the development of a conditionally replicative adenovirus for the treatment of breast cancer. As an initial approach to direct the replication of the virus to breast epithelial cells in a controlled fashion, we used a promoter containing EREs. Only in cells that express ERs can the circulating estrogens activate this promoter. The use of EREs may also offer several advantages. First, this strategy allows the exogenous modulation of the virus by administration of antiestrogens such as tamoxifen, which is a well-tolerated drug extensively used in humans for the treatment and prevention of hormone-sensitive breast cancers. In addition, if a local or regional treatment is envisioned, the ERs can provide a preferential replication of the virus in malignant breast epithelial cells versus the surrounding parenchyma. Finally, although other tissues can express ERs, it is not clear that in all cases the levels and subtypes of receptors ( $\mathrm{ER} \alpha$ or $\mathrm{ER} \beta$ ) can stimulate viral replication.

In the Ad5ERE2 virus, two early transcription units (E1a and E4) are conditionally expressed. As both are necessary for an efficient viral replication, we believe that this contributes to the 


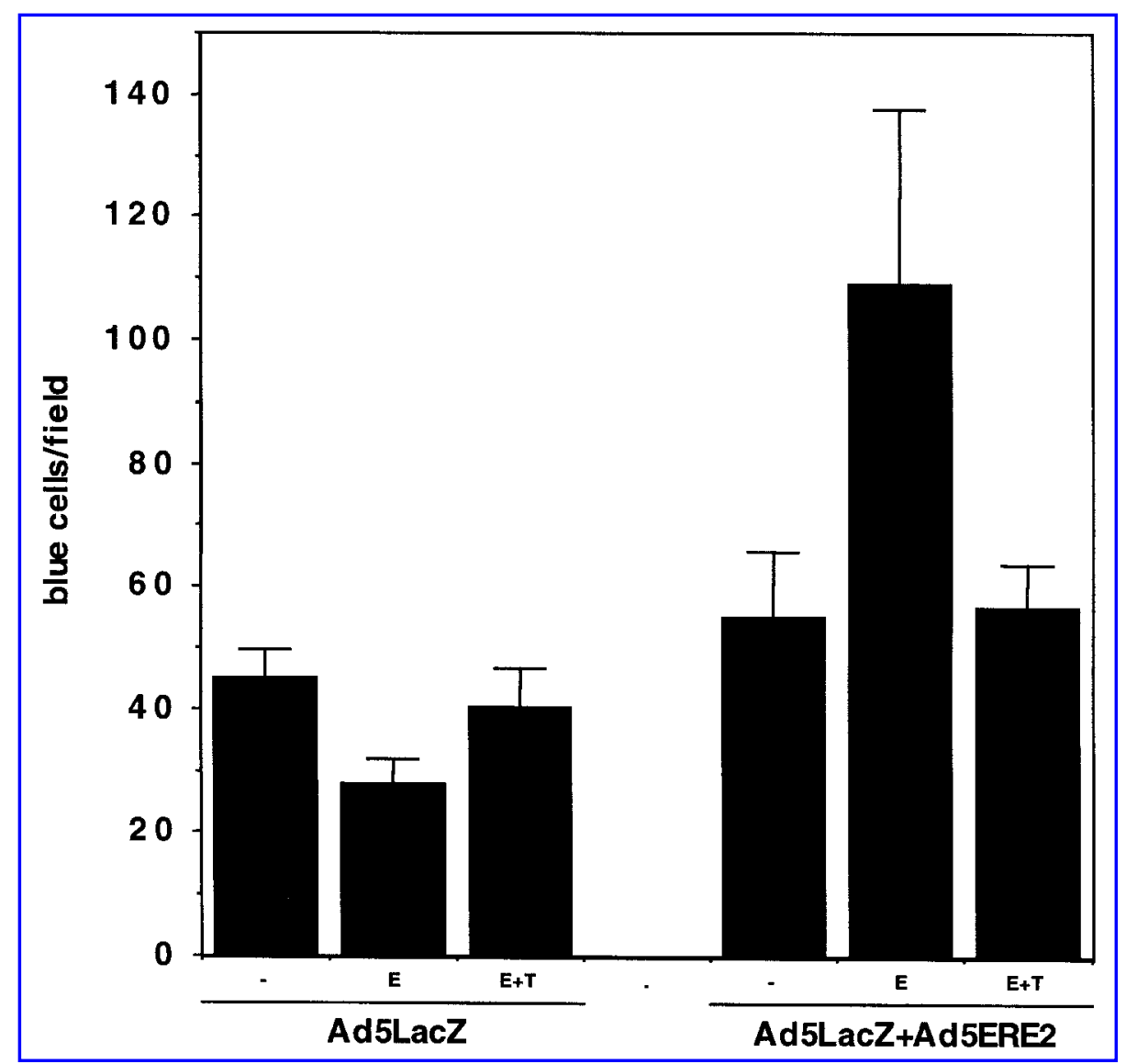

FIG. 8 Complementation of an E1a-deleted adenovirus vector with Ad5ERE2. T47D cells were grown in 12-well plates and infected with a suboptimal amount (MOI of 5 virus/cell) of a replication-deficient E1a-deleted adenoviral vector expressing the $\beta$-galactosidase gene (Ad5LacZ). The cells were maintained in phenol red-free medium with $2.5 \%$ charcoal-dextran stripped serum, and left untreated (-) or treated with $2 \mathrm{n} M 17 \beta$-estradiol (E) or $2 \mathrm{n} M 17 \beta$-estradiol plus $2.5 \mu M 4-\mathrm{OH}$-tamoxifen (E + T). Duplicate wells were infected with the same amount of Ad5LacZ plus Ad5ERE2 at an MOI of 1 virus/cell. Five days after infection, the monolayers were fixed and incubated with X-Gal as described in Materials and Methods. The number of Ad5LacZinfected cells (blue cells) was counted in five different fields of each well. The assay was repeated two times with similar results.

control of the virus and constitutes a safety mechanism to prevent the appearance of wild-type revertants. Moreover, E4 functions have been implicated in virus-induced $\mathrm{CPE}$ and death of infected cells. In this way, the control of the E4 ORF expression can direct not only the replication, but also the lethal effect of the virus on the cancer cells, which is the final goal of therapeutic viruses. In the present study we demonstrate that the cytotoxic effect of the Ad5ERE2 virus can be modulated by the addition of estrogenic agonists/antagonists. More importantly, using several well-defined human tumor

FIG. 9. Use of Ad5ERE2 to amplify the lethal effect of an E1a-deleted adenovirus vector expressing the proapoptotic gene Bcl-xs. (A) MCF7 cells (typically $5 \times 10^{4} /$ well in a 12-well plate) were infected with suboptimal amounts of Ad5Bcl-xs (MOI of 2 and 20 virus/cell, as indicated), in the presence of $1.5 \mathrm{n} M 17 \beta$-estradiol. In some of the monolayers, Ad5ERE2 was added at an MOI of 0.5 virus/cell. When indicated, $2 \mu M$ 4-OH-tamoxifen was added (T). Panel 1 shows uninfected cells, and panels 2 and 3 show cells infected with Ad5ERE2 alone (MOI of 0.5) or Ad5Bclx-s alone (MOI of 2), respectively. In panels 4 and 5 , cells were infected with the indicated titers of both viruses together, with addition of tamoxifen only in panel 5 . Panel 6 shows cells infected with Ad5Bcl-xs alone (MOI of 20). In panels 7 and 8, cells were infected with Ad5Bcl-xs (MOI of 20) plus Ad5ERE2 (MOI of 0.5), with addition of tamoxifen only in panel 8. The cells were refed with new medium every 3 days, and representative $\times 400$ (original magnification) fields were photographed after 8 days of infection. The experiment was repeated three times with similar results. (B) In an independent experiment, MCF7 cells were treated essentially as described above. Ad5Bcl-xs was added at an MOI of 200 virus/cell, alone or in combination with Ad5ERE2 at an MOI of 0.25 virus/cell. In the same way, Ad5 $\Delta$ E1a was used at an MOI of 200, alone or in combination with Ad5ERE2. After 8 days of infection, the viability of the cells was analyzed by the MTT assay, as described in Materials and Methods. The experiment was repeated two times with similar results. The significance of the differences observed was statistically analyzed by the $t$ test. 
A
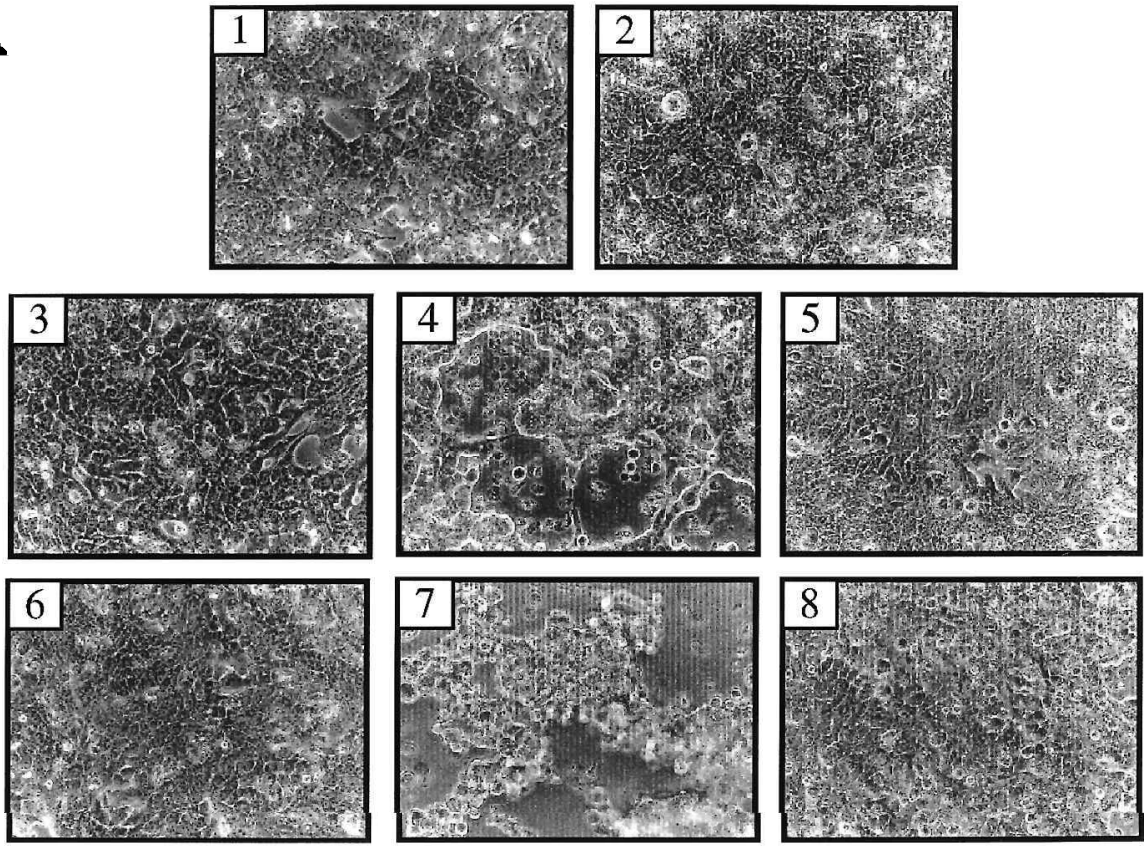

1.- Control

2.- ERE2

3.- Bcl-xs MOI 2

4.- Bcl-xs MOI $2+$ ERE2
5. $\mathrm{Bcl}-\mathrm{xs}$ MOI $2+\mathrm{ERE} 2+\mathrm{T}$

6.- Bcl-xs MOI 20

7.- Bcl-xs MOI $20+$ ERE2

8.- Bcl-xs MOI $20+\mathrm{ERE} 2+\mathrm{T}$

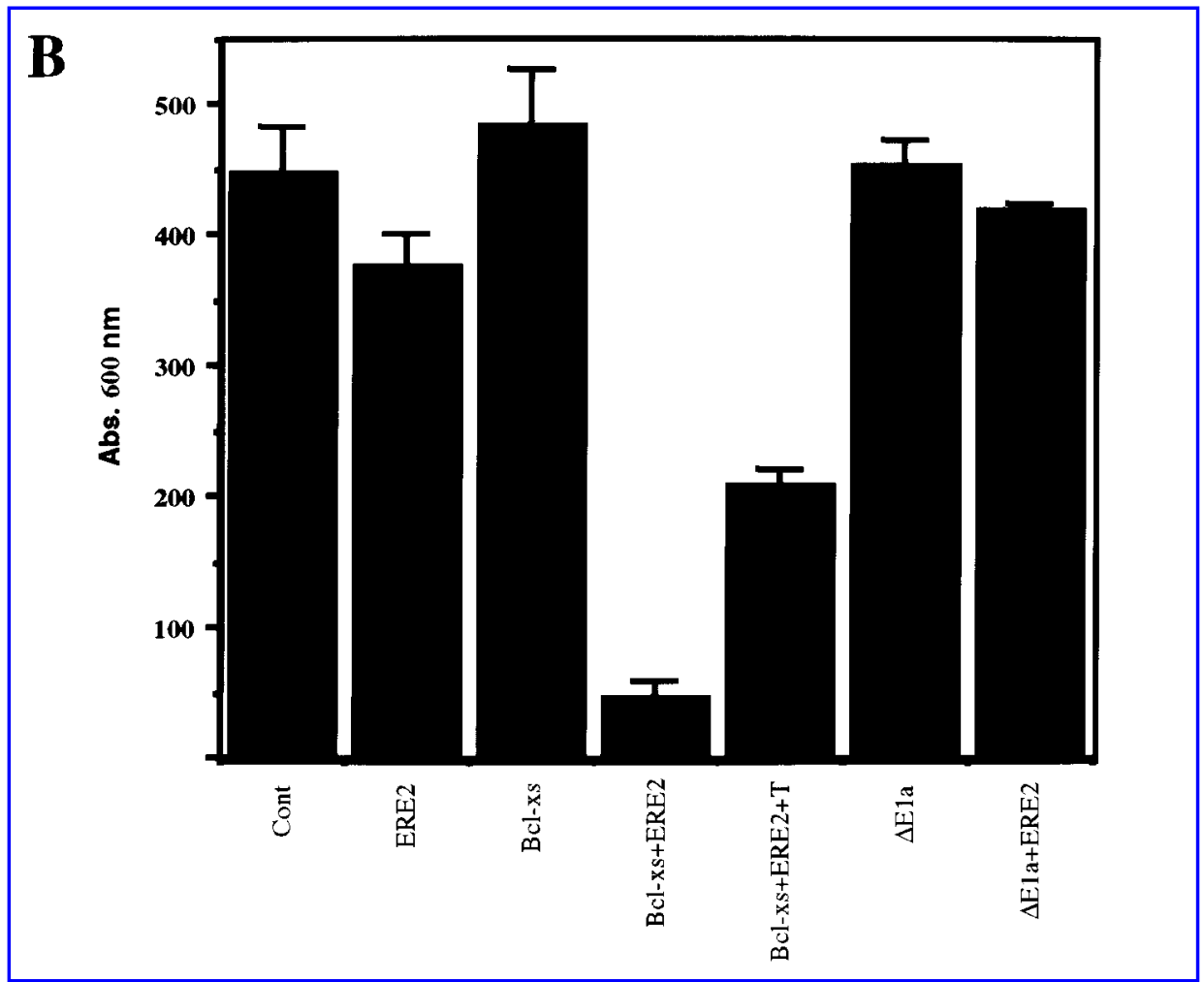




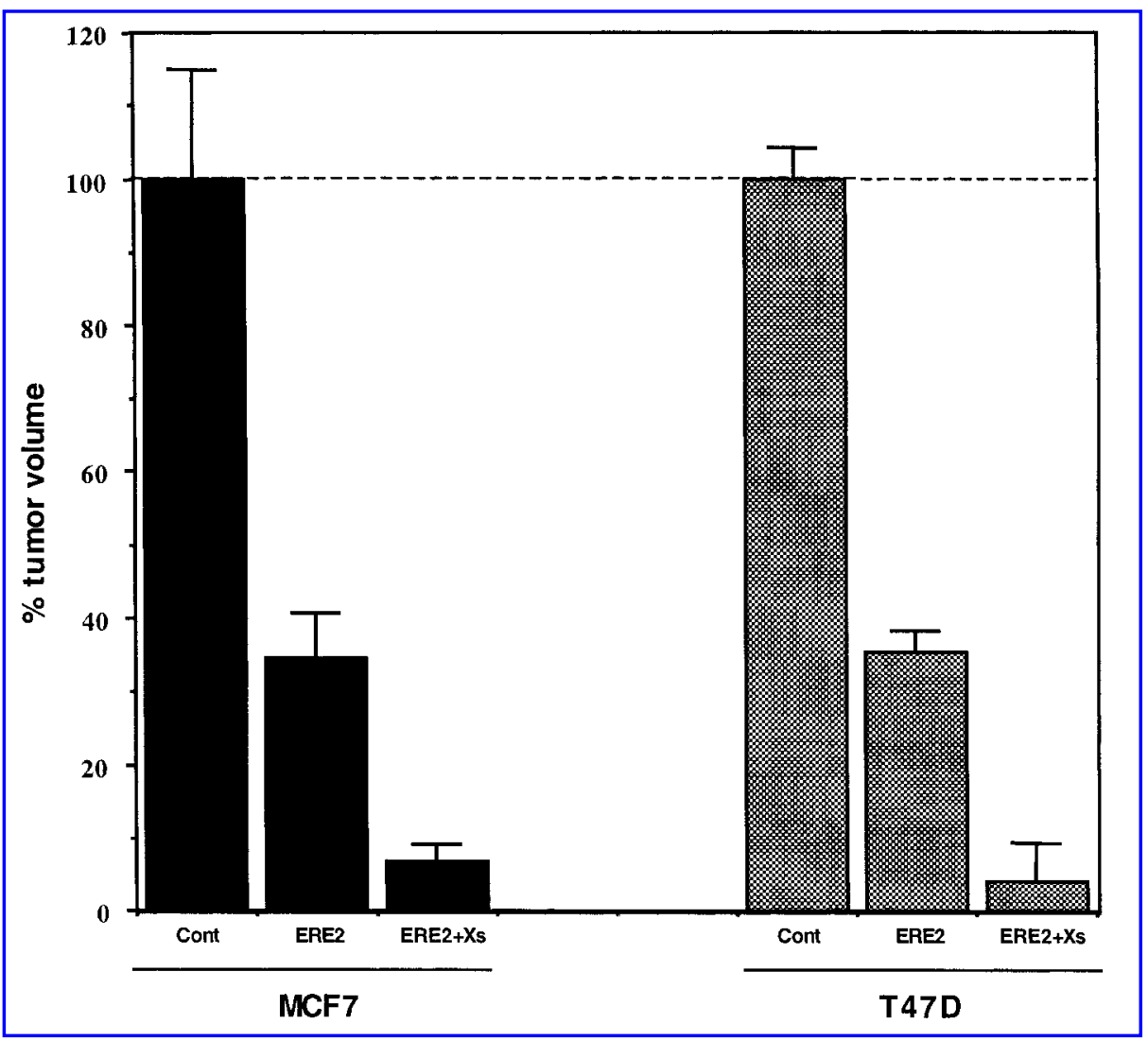

FIG. 10. Antitumoral effect of Ad5ERE2 in combination with Ad5Bcl-xs. Human tumor xenografts were established in nude mice by injection of MCF7 or T47D cells as described in Materials and Methods. In the case of MCF7, the tumors were randomized in three different groups $(n=3)$, which received one weekly intratumoral injection of vehicle alone $(\mathrm{Cont}), 10^{7} \mathrm{PFU}$ of Ad5ERE2 (ERE2), or $10^{7}$ PFU of Ad5ERE2 plus $10^{8}$ PFU of Ad5Bclxs (ERE2 + Xs). The T47D tumors received the same treatments except that the Ad5ERE2 dose was $5 \times 10^{7}$ PFU/tumor. Presented here is the average reduction of tumor volume 20 days after initiation of the treatment. The differences between each group were statistically significant $(p<0.05)$.

cells we show evidence that the virus preferentially kills $\mathrm{ER}^{+}$ cells.

Conditionally replicative adenoviruses can act as a therapeutic tool themselves, but they can also deliver lethal genes to cancer cells to enhance their effect. In this way, the addition of a cassette for the expression of proapoptotic genes or prodrugconverting enzymes such as thymidine kinase or cytosine deaminase is technically possible (Wildner et al., 1999). However, a conditionally replicative adenovirus can also be used to amplify the effect of any E1a-deleted adenoviral vector (Motoi et $a l ., 2000)$. We demonstrate that such viruses can be used to amplify a cytotoxic replication-deficient virus expressing the Bclxs gene, which is selectively toxic to transformed cells (Clarke et al., 1995). The controlled replication of an adenovirus expressing such a gene can provide an additional level of specificity. The cooperation of Ad5ERE2 and Ad5Bcl-xs was demonstrated both in vitro and in vivo, using human tumor xenografts growing in nude mice.

In summary, the use of EREs to control the expression of E1a and E4 genes is a promising method for the construction of conditionally replicative viruses that can enhance cancer gene therapy strategies. It combines in the same therapeutic agent the targeting properties of the tissue-specific promoters with the exogenous modulation of the drug-regulated gene expression systems. We are currently using this approach to investigate the use of new hybrid promoters with improved tissue specificity as well as tumor-specific elements such as the hypoxia response elements.

\section{ACKNOWLEDGMENTS}

We thank D. Qiang for technical support; B.S. Katzenellenbogen and K. Weis for the pERE2pS2CAT plasmid and useful information; G. Nuñez for the pCDNA3 $\beta$ Gal plasmid; $M$. Mehtali for the pTG3602 plasmid; B. Vogelstein for pAdTrack and pShuttle plasmids; S.P. Ethier for the SUM-309PE cell line; L. del Peso for many helpful discussions; and Laurie Kittl for correction of the manuscript. This work was supported by NIH grants CA 75136 and CA 67140. 


\section{REFERENCES}

BERRY, M., NUÑEZ, A.M., and CHAMBON, P. (1989). Estrogen-responsive element of the human pS2 gene is an imperfectly palindromic sequence. Proc. Natl. Acad. Sci. U.S.A. 86, 1218-1222.

BISCHOFF, J., KIRN, D., WILlIAMS, A., HEISE, C., HORN, S., MUNA, M. NG, L., NYE, J.A., SAMPSON-JOHANNES, A., FATTAEY, A., and MCCORMICK, F. (1996). An adenovirus mutant that replicates selectively in p53-deficient human tumor cells. Science 274, 373-376.

CARMICHAEL, J., DEGRAFF, W.G., GAZDAR, A.F., MINNA, J.D., and MITCHELL, J.B. (1987). Evaluation of a tetrazolium-based semiautomated colorimetric assay: Assessment of chemosensitivity testing. Cancer Res. 47, 936-942.

CHARTIER, C., DEGRYSE, E., GANTZER, M., DIETERLE, A., PAVIRANI, A., and MEHTALI, M. (1996). Efficient generation of recombinant adenovirus vectors by homologous recombination in Escherichia coli. J. Virol. 70, 4805-4810.

CLARCKSON, T. (2000). Regulated gene expression systems. Gene Ther. 7, 120-125.

CLARKE, M.F., APEL, I.J., BENEDICT, M.A., EIPERS, P.G., SUMANTRAN, V., GONZALEZ-GARCIA, M., DOEDENS, M., FUKUNAGA, N., DAVIDSON, B., DICK, J.E., MINN, A.J., BOISE, L.H., THOMPSON, C.B., WICHA, M.W., and NUÑEZ, G. (1995). A recombinant bcl-xs adenovirus selectively induces apoptosis in cancer cells but not in normal bone marrow cells. Proc. Natl. Acad. Sci. U.S.A. 92, 11024-11028.

DRANOFF, G. (1998). Cancer gene therapy: Connecting basic research with clinical inquiry. J. Clin. Oncol. 16, 2548-2556.

EALOVENGA, M.W., McGINNIS, P.K., SUMANTRAN, V.N., CLARKE, M.F., and WICHA, M.S. (1996). Bclx-s gene therapy induces apoptosis of human mammary tumors in nude mice. $\underline{\text { Cancer }}$ Res. 56, 1965-1969.

EKENA, K., KATZENELLENBOGEN, J.A., and KATZENELLENBOGEN, B.S. (1998). Determinants of ligand specificity of estrogen receptor- $\alpha$ : Estrogen versus androgen discrimination. J. Biol. Chem. 273, 693-699.

FALGOUT, B., and KETNER, G. (1987). Adenovirus early region 4 is required for efficient virus particle assembly. J. Virol. 61, 3759-3768.

FUEYO, J., GOMEZ-MANZANO, C., ALEMANY, R., LEE, P.S., McDONNELL, T.J., MITLIANGA, P., SHI, Y.X., LEVIN, V.A., YUNG, W.K., and KYRITSIS, A.P. (2000). A mutant oncolytic adenovirus targeting the $\mathrm{Rb}$ pathway produces anti-glioma effect in vivo. Oncogene 19, 2-12.

GAO, G.P., YANG, Y., and WILSON, J.M. (1996). Biology of adenovirus vectors with $\mathrm{E} 1$ and $\mathrm{E} 4$ deletions for liver-directed gene therapy. J. Virol. 70, 8934-8943.

HALBERT, D.N., CUTT, J.R., and SHENK, T. (1985). Adenovirus early region 4 encodes functions required for efficient DNA replication, late gene expression, and host cell shutoff. J. Virol. 56, 250-257.

HALL, A.R., DIX, B.R., O'CARROLL, S.J., and BRAITHWAITE, A.W. (1998). p53 cell death/apoptosis is required for a productive adenovirus infection. Nature Med. 4, 1068-1072.

HALLENBECK, P.L., CHANG, Y., HAY, C., GOLIGHTLY, D., STEWART, D., LIN, J., PHIPPS, S., and CHIANG, Y.L. (1999). A novel tumor-specific replication-restricted adenoviral vector for gene therapy of hepatocellular carcinoma. Hum. Gene Ther. 10, 1721-1733.

HAN, J., QIAN, D., WICHA, M., and CLARKE, M. (1998). A method of limited replication for the efficient in vivo delivery of adenovirus to cancer cells. Hum. Gene Ther. 9, 1209-1216.

HAY, J., SHAPIRO, N., SAUTHOFF, H., HEINTER, S., PHUPAKDI, W., and ROM, W. (1999). Targeting the replication of adenoviral gene therapy vectors to lung cancer cells: the importance of the E1b$55 \mathrm{kD}$ gene. Hum. Gene Ther. 10, 579-590.

HE, T.C., ZHOU, S., DA COSTA, L.T., YU, J., KINZLER, K.W., and VOGELSTEIN, B. (1998). A simplified system for generating recombinant adenoviruses. Proc. Natl. Acad. Sci. U.S.A. 95, 2509-2514.

HEISE, C.C., SAMPSON-JOHANNES, A., WILLIAMS, A., McCORMICK, F., VON HOFF, D.O., and KIRN, D.H. (1997). ONYX015, and E1B gene-attenuated adenovirus, causes tumor-specific cytolysis and antitumoral efficacy that can be augmented by standard chemotherapeutic agents. Nature Med. 3, 639-645.

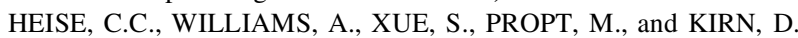
(1999). Intravenous administration of ONYX-015, a selectively replicating adenovirus, induces antitumoral efficacy. Cancer Res. 59, 2623-2628.

JELTSCH, J.M., ROBERTS, M., SCHATZ, C., GARNIER, J.M., DROWN, A.M., and CHAMBON, P. (1987). Structure of the human oestrogen-responsive gene pS2. Nucleic Acids Res. 15, 1401-1414. KIRN, D., HERMISTON, T., and McCORMICK, F. (1998). ONYX015: Clinical data are encouraging. Nature Med. 4, 1341-1342.

LILLIE, J.W., and GREEN, M.R. (1989). Transcription activation by the adenovirus E1 a protein. Nature (London) 338, 39-44.

LUSKY, M., CHRIST, M., RITTNER, K., DIETERLE, A., DREYER, D., MOUROT, B., SCHULTZ, H., STOECKEL, F., PAVARANI, A., and MEHTALI, M. (1998). In vitro and in vivo biology of recombinant adenovirus vectors with E1, E1/E2A, or E1/E4 deleted. J. Virol. 72, 2022-2232.

MARCELLUS, R.C., LAVOIE, J.N., BOIVIN, D., SHORE, G.C., KETNER, G., and BRANTON, P.E. (1998). The early region 4 orf 4 protein of human adenovirus type 5 induces $\mathrm{p} 53$-independent death by apoptosis. J. Virol. 72, 7144-7153.

MONTANO, M.M., EKENA, K., KRUEGER, K.D., KELLER, A.N., and KATZENELLENBOGEN, B.S. (1996). Human estrogen receptor ligand activity inversion mutants: Receptors that interpret antiestrogens as estrogens and estrogens as antiestrogens and discriminate among different antiestrogens. Mol. Endocrinol. 10, 230-242. MOTOI, F., SUNAMURA, M., DING, L., DUDA, D.G., YOSHIDA, Y., ZHANG, W., MATSUNO, S., and HAMADA, H. (2000). Effective gene therapy for pancreatic cancer by cytokines mediated by restricted replication-competent adenovirus. Hum. Gene Ther. 11, 223-235.

PENG, K., and VILE, R. (1999). Vector development for cancer gene therapy. Tumor Target. 4, 3-11.

RIBIERAS, S., TOMASETTO, C., and RIO, M.C. (1998). The $\mathrm{pS} 2 / \mathrm{TFF} 1$ trefoil factor, from basic research to clinical applications. Biochim. Biophys. Acta 1378, F61-F77.

RIO, M.C., and CHAMBON, P. (1990). The pS2 gene, mRNA and pro-

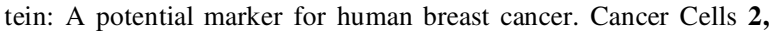
269-274.

ROTH, J., and CRISTIANO, R. (1997). Gene therapy for cancer: What have we done and where are we going? J. Natl. Cancer Inst. 89, 21-39.

ROTHMANN, T., HENGSTERMANN, A., WHITAKER, N., SCHEFFNER, M., and HAUSEN, H. (1998). Replication of ONYX015 , a potential anticancer adenovirus, is independent of p53 status in tumor cells. J. Virol. 72, 9470-9478.

SHENK, T. (1996). Adenoviridae: The viruses and their replication. In Fields Virology. B.N. Fields, D.M.. Knipe, and P.M. Howley, eds. (Lippincott-Raven, Philadelphia, PA) pp. 2111-2147.

SHI, Q., WANG, Y., and WORTON, R. (1997). Modulation of the specificity and activity of a cellular promoter in an adenoviral vector. Hum. Gene Ther. 8, 403-410.

SHTRICHMAN, R., and KLEINBERGER, T. (1998). Adenovirus type 5 E4 open reading frame 4 protein induces apoptosis in transformed cells. J. Virol. 72, 2975-2982.

TSAI, M.J., and O'MALLEY, B.M. (1994). Molecular mechanisms of action of steroid/thyroid receptor superfamily members. Annu. $\underline{\text { Rev }}$. Biochem. 63, 451-486. 
VALAVAARA, R. (1997). Reliability of estrogen receptors in predicting response to antiestrogens. Oncology 11, 14-18.

VASSAUX, G., HURST, H.C., and LEMOINE, N.R. (1999). Insulation of a conditionally expressed transgene in an adenoviral vector. Gene Ther. 6, 1192-1197.

VELCULESCU, V., ZHANG, L., VOGELSTEIN, B., and KINZLER, K. (1995). Serial analysis of gene expression. Science 270, 484-487.

VILE, R.G., RUSSELL, S.J., and LEMOINE, N.R. (2000). Cancer gene therapy: Hard lessons and new courses. Gene Ther. 7, $2-8$.

WILDNER, O., BLAESE, R.M., and MORRIS, J.C. (1999). Therapy of colon cancer with oncolytic adenovirus is enhanced by the addition of herpex simplex virus-thymidine kinase. Cancer Res. 59, 410-413.

YU, D., SAKAMOTO, G.T., and HENDERSON, D.R. (1999). Identification of the transcriptional regulatory sequences of human kallikrein 2 and their use in the construction of Calydon virus 764, an attenuated replication competent adenovirus for prostate cancer therapy. Cancer Res. 59, 1498-1504.

Address reprint requests to: Dr. Michael F. Clarke Department of Internal Medicine-Hematology/Oncology University of Michigan Comprehensive Cancer Center 1500 E. Medical Ctr. Drive, 4-310 CCGC Ann Arbor, MI 48109-0936

E-mail: mclarke@umich.edu

Received for publication March 14, 2000; accepted after revision July 5, 2000. 


\section{This article has been cited by:}

1.J A Coulter, H O McCarthy, J Worthington, T Robson, S Scott, D G Hirst. 2008. The radiation-inducible $\mathrm{pE} 9$ promoter driving inducible nitric oxide synthase radiosensitizes hypoxic tumour cells to radiation. Gene Therapy 15:7, 495-503. [CrossRef]

2. Sergia Bortolanza, Pilar Alzuguren, Maria Buñuales, Cheng Qian, Jesus Prieto , Ruben Hernandez-Alcoceba . 2007. Human Adenovirus Replicates in Immunocompetent Models of Pancreatic Cancer in Syrian HamstersHuman Adenovirus Replicates in Immunocompetent Models of Pancreatic Cancer in Syrian Hamsters. Human Gene Therapy 18:8, 681-690. [Abstract] [PDF] [PDF Plus]

3. P H Abbosh, X Li, L Li, T A Gardner, C Kao, K P Nephew. 2007. A conditionally replicative, Wnt/ $\beta$-catenin pathway-based adenovirus therapy for anaplastic thyroid cancer. Cancer Gene Therapy 14:4, 399-408. [CrossRef]

4.X Zheng, X-M Rao, C L Snodgrass, K M McMasters, H S Zhou. 2006. Selective replication of E1B55K-deleted adenoviruses depends on enhanced E1A expression in cancer cells. Cancer Gene Therapy 13:6, 572-583. [CrossRef]

5. I Sipo, X Wang, A Hurtado Picó, L Suckau, S Weger, W Poller, H Fechner. 2006. Tamoxifen-regulated adenoviral E1A chimeras for the control of tumor selective oncolytic adenovirus replication in vitro and in vivo. Gene Therapy 13:2, 173-186. [CrossRef]

6. Kirsi Saukkonen, Akseli Hemminki. 2004. Tissue-specific promoters for cancer gene therapy. Expert Opinion on Biological Therapy 4:5, 683-696. [CrossRef]

7. Dirk M. Nettelbeck. 2003. Virotherapeutics: conditionally replicative adenoviruses for viral oncolysis. Anti-Cancer Drugs 14:8, 577-584. [CrossRef]

8. Dawn E. Post, Fadlo R. Khuri , Jonathan W. Simons, Erwin G. van Meir . 2003. Replicative Oncolytic Adenoviruses in Multimodal Cancer RegimensReplicative Oncolytic Adenoviruses in Multimodal Cancer Regimens. Human Gene Therapy 14:10, 933-946. [Abstract] [PDF] [PDF Plus]

9. John Nemunaitis. 2003. Selective Replicating Viral Vectors. BioDrugs 17:4, 251-262. [CrossRef]

10. CMF Dirven, VW van Beusechem, MLM Lamfers, J Grill, WR Gerritsen, WP Vandertop. 2003. Oncolytic adenoviruses for treatment of brain tumours. Expert Opinion on Biological Therapy 2:8, 943-952. [CrossRef]

11. Ruben Hernandez-Alcoceba, Michael Pihalja , Dalong Qian, Michael F. Clarke . 2002. New Oncolytic Adenoviruses with Hypoxia- and Estrogen Receptor-Regulated ReplicationNew Oncolytic Adenoviruses with Hypoxia- and Estrogen Receptor-Regulated Replication. Human Gene Therapy 13:14, 1737-1750. [Abstract] [PDF] [PDF Plus]

12. John Nemunaitis, John O'Brien. 2002. Head and neck cancer: Gene therapy approaches. Part 1: Adenoviral vectors. Expert Opinion on Biological Therapy 2:2, 177-185. [CrossRef]

13. Akseli Hemminki, Ronald D. Alvarez. 2002. Adenoviruses in Oncology. BioDrugs 16:2, 77-87. [CrossRef]

14. Denise Harrison, Harald Sauthoff, Sheila Heitner, Jaishree Jagirdar, William N. Rom, John G. Hay . 2001. Wild-Type Adenovirus Decreases Tumor Xenograft Growth, but Despite Viral Persistence Complete Tumor Responses Are Rarely Achieved-Deletion of the Viral E1b-19-kD Gene Increases the Viral Oncolytic EffectWild-Type Adenovirus Decreases Tumor Xenograft Growth, but Despite Viral Persistence Complete Tumor Responses Are Rarely Achieved-Deletion of the Viral E1b-19-kD Gene Increases the Viral Oncolytic Effect. Human Gene Therapy 12:10, 1323-1332. [Abstract] [PDF] [PDF Plus] 